Prepared for the U.S. Department of Energy under Contract DE-AC05-76RL01830

\title{
Renewable Energy Assessment Methodology for Japanese OCONUS Army Installations
}
AE Solana
WJ Gorrissen
JR Hand
JA Horner
AR Kora
AC Orrell
BJ Russo
MR Weimar
JL Williamson

August 2010

Pacific Northwest

NATIONAL LABORATORY

Proudly Operated by Battelle Since 1965 


\title{
DISCLAIMER
}

This report was prepared as an account of work sponsored by an agency of the United States Government. Neither the United States Government nor any agency thereof, nor Battelle Memorial Institute, nor any of their employees, makes any warranty, express or implied, or assumes any legal liability or responsibility for the accuracy, completeness, or usefulness of any information, apparatus, product, or process disclosed, or represents that its use would not infringe privately owned rights. Reference herein to any specific commercial product, process, or service by trade name, trademark, manufacturer, or otherwise does not necessarily constitute or imply its endorsement, recommendation, or favoring by the United States Government or any agency thereof, or Battelle Memorial Institute. The views and opinions of authors expressed herein do not necessarily state or reflect those of the United States Government or any agency thereof.

\author{
PACIFIC NORTHWEST NATIONAL LABORATORY \\ operated by \\ BATTELLE \\ for the \\ UNITED STATES DEPARTMENT OF ENERGY \\ under Contract DE-AC05-76RL01830
}

Printed in the United States of America
Available to DOE and DOE contractors from the Office of Scientific and Technical Information,
P.O. Box 62, Oak Ridge, TN 37831-0062;
ph: (865) 576-8401
fax: (865) 576-5728
email: reports@adonis.osti.gov

\author{
Available to the public from the National Technical Information Service, \\ U.S. Department of Commerce, 5285 Port Royal Rd., Springfield, VA 22161 \\ ph: (800) 553-6847 \\ fax: (703) 605-6900 \\ email: orders@ntis.fedworld.gov \\ online ordering: http://www.ntis.gov/ordering.htm
}

This document was printed on recycled paper. 


\section{Renewable Energy As ses sment Methodology for Japanes e OCONUS Army Ins tallations}
AE Solana
WJ Gorrissen
JR Hand
JA Horner
AR Kora
AC Orrell
BJ Russo
MR Weimar
JL Williamson

August 2010

Prepared for

Office of the Assistant Secretary of the Army for Installations and Environment

under Contract DE-AC05-76RL01830

Pacific Northwest National Laboratory

Richland, Washington 99352 



\section{Executive Summary}

Since 2005, Pacific Northwest National Laboratory (PNNL) has been asked by Installation Management Command (IMCOM) to conduct strategic assessments at selected US Army installations of the potential use of renewable energy resources, including solar, wind, geothermal, biomass, waste, and ground source heat pumps (GSHPs). IMCOM has the same economic, security, and legal drivers to develop alternative, renewable energy resources overseas as it has for installations located in the US. The approach for continental US (CONUS) studies has been to use known, USbased renewable resource characterizations and information sources coupled with local, site-specific sources and interviews. However, the extent to which this sort of data might be available for outside the continental US (OCONUS) sites was unknown.

An assessment at Camp Zama, Japan was completed as a trial to test the applicability of the CONUS methodology at OCONUS installations. It was found that, with some help from Camp Zama personnel in translating and locating a few Japanese sources, there was relatively little difficulty in finding sources that should provide a solid basis for conducting an assessment of comparable depth to those conducted for US installations. Project implementation will likely be more of a challenge, but the feasibility analysis will be able to use the same basic steps, with some adjusted inputs, as PNNL's established renewable resource assessment methodology. 
Renewable Energy Assessment Methodology for Japanese OCONUS Army Installations Pacific Northwest National Laboratory, August 2010 


\section{Table of Contents}

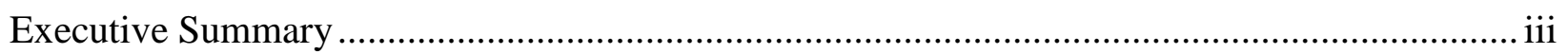

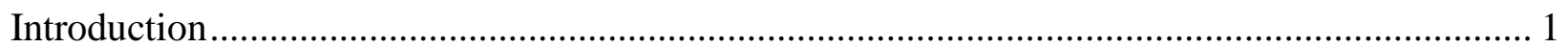

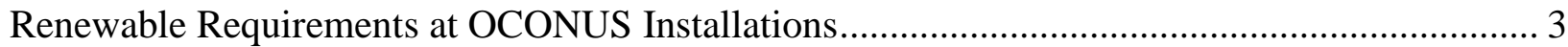

Political and Economic Environment for Renewables in Japan ..................................................... 5

Economic Evaluation of OCONUS Renewable Projects......................................................... 7

Incentives and Other Parameters .................................................................................. 7

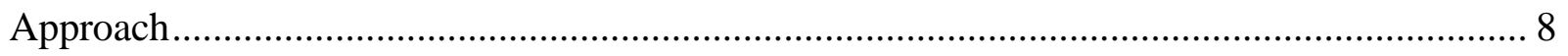

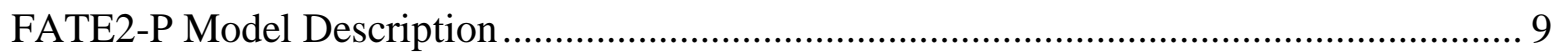

Facility Energy Decision System (FEDS) Model ........................................................... 10

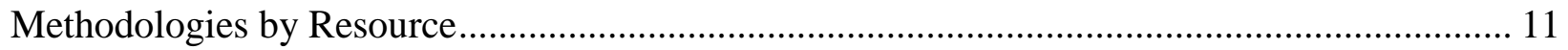

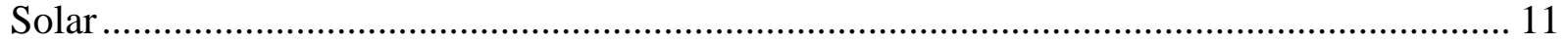

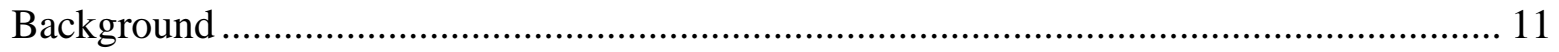

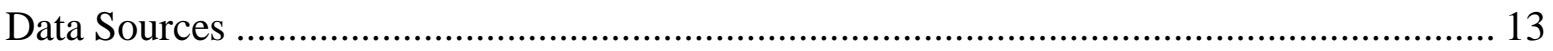

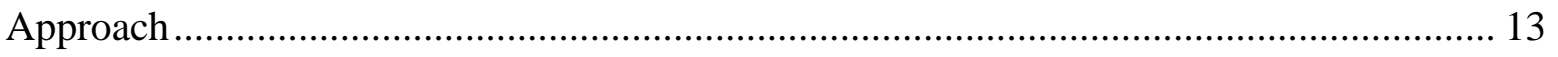

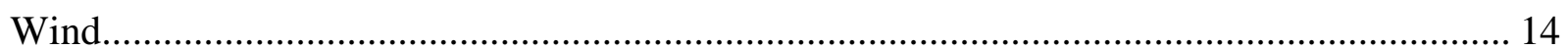

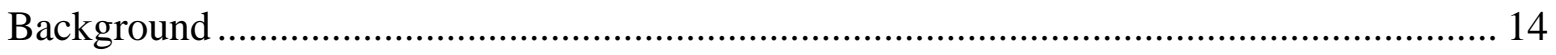

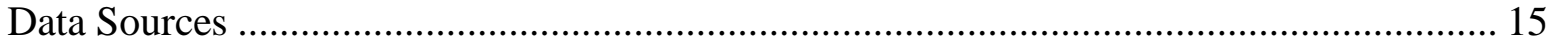

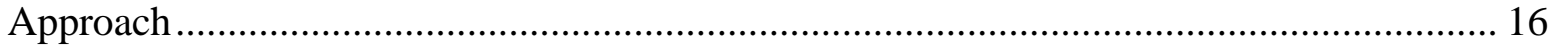

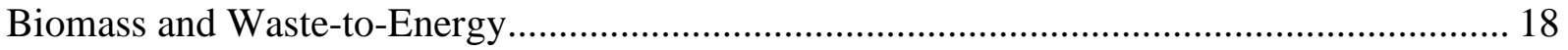

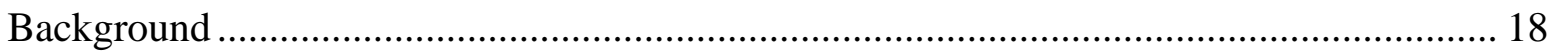

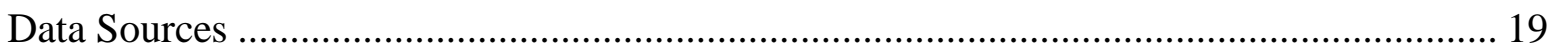

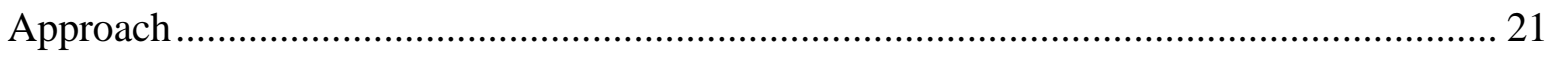

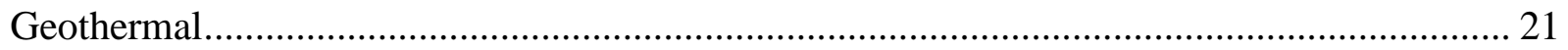

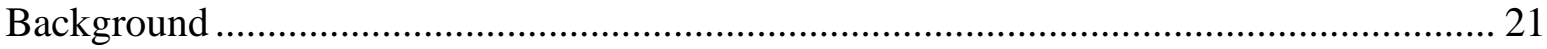

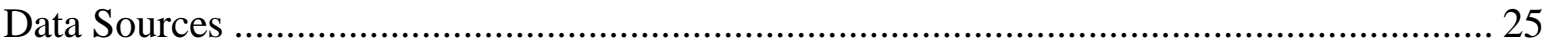

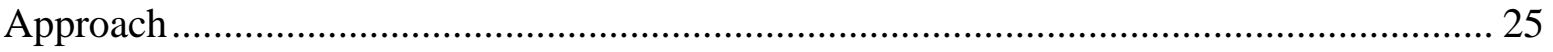

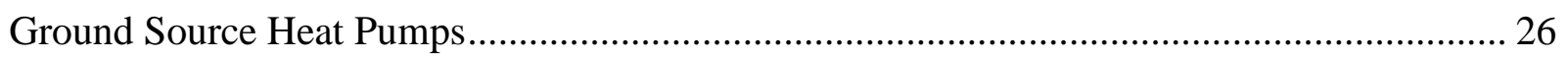

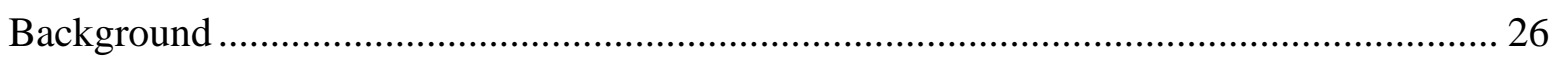

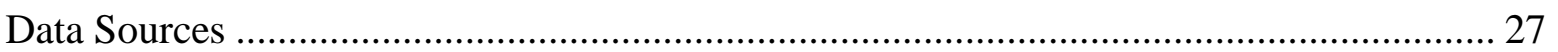

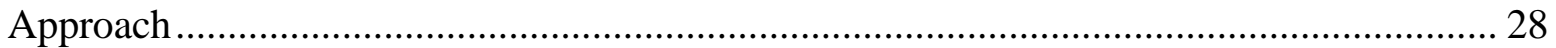

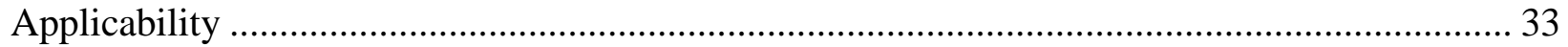

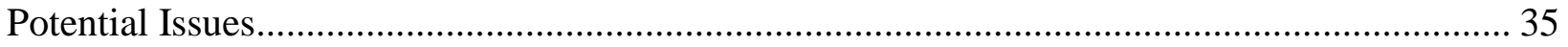

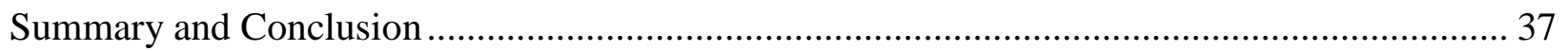

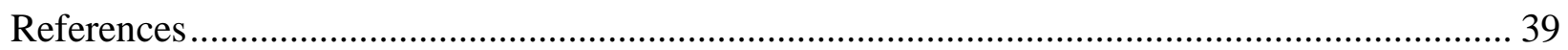




\section{Figures}

Figure 1: Total 2005 Energy Consumption in Japan, by Type ................................................ 5

Figure 2: 2008 Renewable Energy Consumption in Japan, by Type....................................... 6

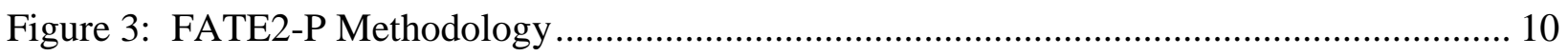

Figure 4: Geothermal Energy Project Locations in Japan ................................................... 23

\section{Tables}

Table 1: Legislated Renewable Energy Targets for DOD ..................................................... 3

Table 2: Discount Rate Assumptions in ECIP Model ......................................................... 9

Table 3: PV Energy Projects in Japan (Lenardic 2010)....................................................... 12

Table 4: PV Module and System Specifications................................................................. 13

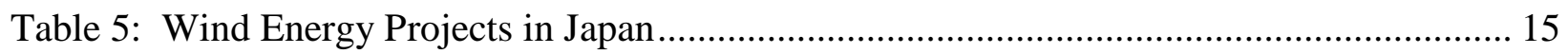

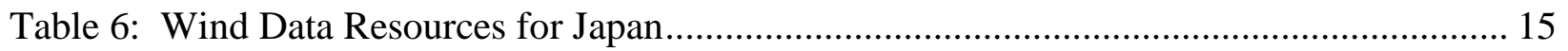

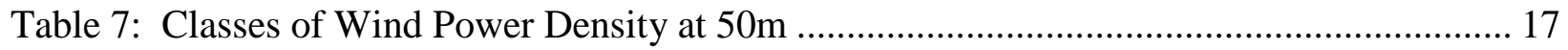

Table 8: Example Biomass Energy Projects in Japan ............................................................ 18

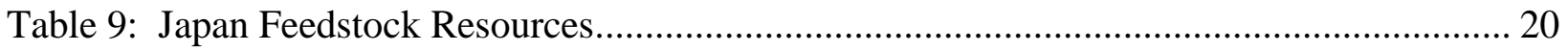

Table 10: Example Geothermal Energy Projects in Japan...................................................... 24

Table 11: Example GSHP Projects in Japan.................................................................... 27 


\section{Introduction}

In 2005, Pacific Northwest National Laboratory (PNNL) led a study to identify utility-scale electricity generation opportunities at Department of Defense (DOD) installations. That study focused on solar photovoltaics (PV), wind, and geothermal opportunities at continental US (CONUS) installations. Since 2005, Installation Management Command (IMCOM) has asked PNNL to conduct strategic assessments of the potential use of a wider range of renewable energy resources at selected US Army installations, including biomass, waste-to-energy (WTE), and ground source heat pumps (GSHPs). The assessments are in response to aggressive federal goals for increasing renewable energy use in federal facilities, Army concerns about the implications of increased fossil fuel prices, and a drive to increase installation energy self-sufficiency (and therefore security). The goal of the analyses is to identify economically feasible opportunities for generation of electricity from renewable resources-generation that is significant enough to warrant connection to the grid and/or to contribute in a meaningful way to the aggressive renewable energy goals of the Army and the Department of Defense (DoD).

IMCOM has the same economic, security, and legal drivers to develop alternative, renewable energy sources overseas as it has for installations located in the US. The drivers include

$\checkmark$ Reducing energy costs and energy cost volatility,

$\checkmark$ Enhancing supply reliability by using local, indigenous sources,

$\checkmark$ Increasing energy resilience and endurance through development of on-site renewable resources,

$\checkmark$ Exposing soldiers to renewable technologies that may be deployed in theater, and

$\checkmark$ Complying with applicable laws and policies.

The approach for CONUS studies has been to use the 2005 DOD renewable energy study plus other known, US-based renewable resource characterizations and information sources coupled with local, site-specific sources and interviews. However, the extent to which this sort of data might be available for outside the continental US (OCONUS) sites was unknown. This report outlines the process to be used to assess renewable energy potential at Japanese, and potentially other, OCONUS installations. 
Renewable Energy Assessment Methodology for Japanese OCONUS Army Installations Pacific Northwest National Laboratory, August 2010 


\section{Renewable Requirements at OCONUS Installations}

Table 1 summarizes the US statutes and policies that apply to both CONUS and OCONUS installations and facilities. Japanese renewable goals do not directly apply to US military installations located on Japanese soil. However, renewables built for the US Army can contribute toward the owning or funding utility's renewable portfolio standard.

Table 1: Legislated Renewable Energy Targets for DOD

\begin{tabular}{|c|c|c|c|c|}
\hline & $\begin{array}{c}\text { EPAct Section } \\
203\end{array}$ & $\begin{array}{c}\text { Executive Order } \\
13423\end{array}$ & $\begin{array}{c}\text { National Defense } \\
\text { Authorization } \\
\text { Act }\end{array}$ & $\begin{array}{c}\text { Energy } \\
\text { Independence } \\
\text { and Security Act }\end{array}$ \\
\hline Target / Goal & $\begin{array}{l}\text { Increasing targets } \\
\text { reaching } 7.5 \% \text { of } \\
\text { electric energy } \\
\text { from renewables }\end{array}$ & $\begin{array}{l}\text { 7.5\% of electric } \\
\text { energy from } \\
\text { renewables; } 50 \% \\
\text { from new (post- } \\
\text { 1998) sources }\end{array}$ & $\begin{array}{l}\text { Equivalent of } \\
\text { 25\% of electric } \\
\text { energy from } \\
\text { renewables }\end{array}$ & $\begin{array}{c}30 \% \text { of hot water } \\
\text { demand from } \\
\text { solar }\end{array}$ \\
\hline Target Dates & 2013 & 2013 & 2025 & $\begin{array}{c}\text { All new } \\
\text { construction / } \\
\text { major renovations }\end{array}$ \\
\hline Mandatory? & Yes & Yes & No & Yes \\
\hline $\begin{array}{l}\text { Considers thermal } \\
\text { energy "renewable"? }\end{array}$ & No & Yes & Yes & N/A \\
\hline
\end{tabular}


Renewable Energy Assessment Methodology for Japanese OCONUS Army Installations Pacific Northwest National Laboratory, August 2010 


\section{Political and Economic Environment for Renewables in Japan}

The Japanese government has historically been focused on carbon reduction actions rather than renewable energy development. While these are related, Japan has primarily purchased carbon credits to reach goals rather than investing in energy efficiency and renewable energy.

In 2009, the Democratic Party of Japan (DPJ) became the ruling party of the House of Representatives and the House of Councilors, replacing the Liberal Democratic Party. The Prime Minister of Japan was appointed in June 2010 to replace Yukio Hatoyama (who resigned after failing to implement the promised removal of Futenma Marine Air Station) (Fackler 2010), but the more aggressive stance of the current government on global climate change policy, energy security, and renewable energy policy will likely not change. The DPJ has committed to a 25\% reduction in greenhouse gas emissions by 2020 compared to 1990 levels, a huge improvement over the former goal of $8 \%$ reduction. The ruling party is also "eager to expand the share of renewables in Japan's energy mix,” rather than solely focus on carbon reduction (Tetsunari and DeWit 2009). However, carbon reduction is still the priority: a draft policy guideline recently released by Japan’s Ministry of Economy, Trade, and Industry (METI) recommends construction of 8 new nuclear plants by 2020 to help reduce greenhouse gas emissions (Associated Press 2010).

METI has set renewable energy targets that stipulate that $1.35 \%$ of Japan's total energy supply must come from renewables, such as wind, solar, and biofuels, by 2010. The target increases to 1.63\% by 2014 (Englander 2008). According to EIA data, in 2007 Japan’s renewable energy generation was about $0.4 \%$, which went down in 2008 to below 2005 levels. Almost $77 \%$ is generated by biomass and waste; $12 \%$ by wind; $11 \%$ by geothermal; and the remaining from solar, tidal, and wave energy (EIA 2008). Figure 1 shows the 2005 total energy consumption resource profile in Japan, and Figure 2 shows the 2008 renewable energy consumption resource profile.

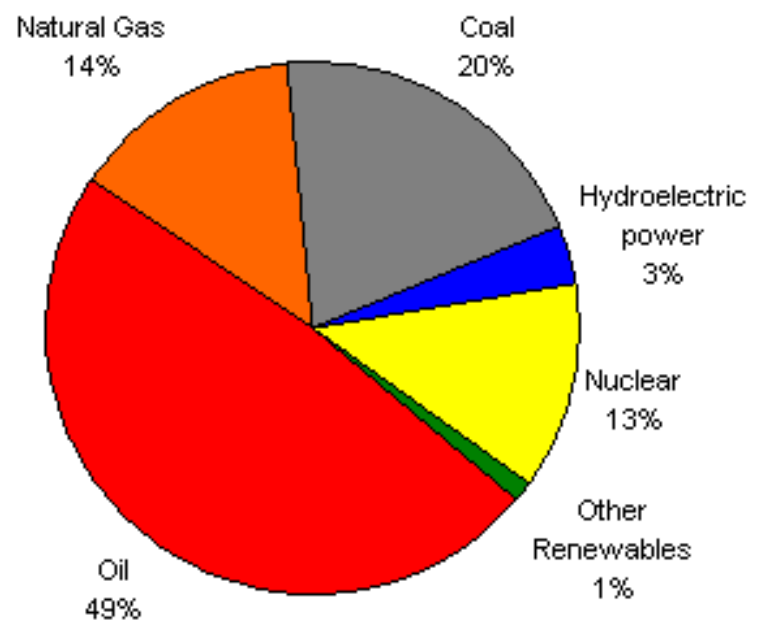

Source: ElA International Energy Annual 2005

Figure 1: Total 2005 Energy Consumption in Japan, by Type

Renewable Energy Assessment Methodology for Japanese OCONUS Army Installations Pacific Northwest National Laboratory, August 2010 


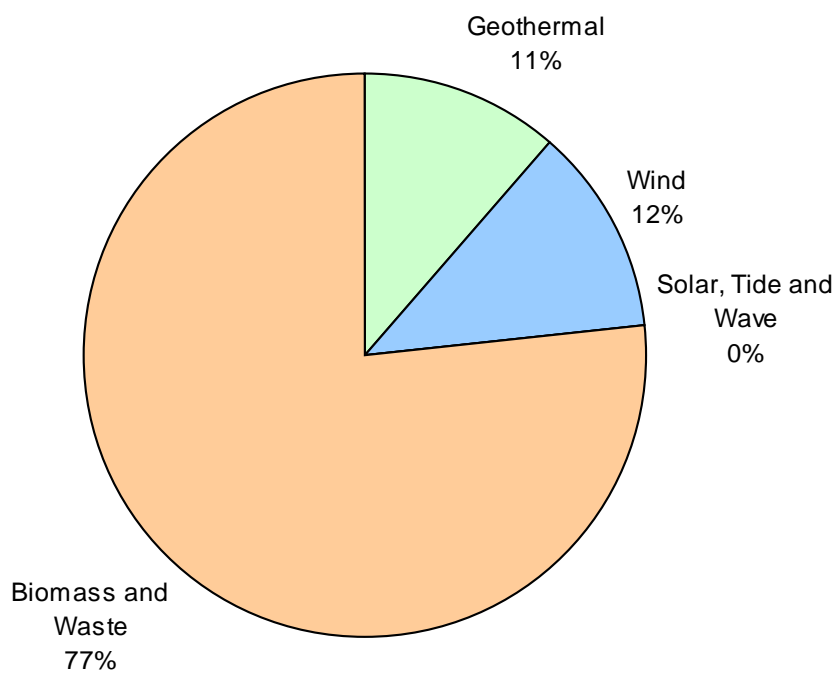

Figure 2: 2008 Renewable Energy Consumption in Japan, by Type

Electricity in Japan is produced by, predominantly, 10 privately-owned power companies. Together they generate over $75 \%$ of Japanese electricity, and control the interconnected transmission and distribution lines. The companies work together to ensure a reliable and stable electric supply for Japan. Unfortunately, this system makes it difficult for independent power producers to contribute renewable (or other) energy to the country's supply (Cleveland 2006).

The US Army purchases electricity from the Japanese utilities, but it is subsidized heavily by the Japanese government through the Utility Cost Sharing (UCS) program, which is part of the Special Measures Agreement between the Government of Japan (GOJ) and the US Forces in Japan (USFJ). The amount of the utility bill subsidized is a fixed sum for FY09 and FY10, but is being renegotiated for FY11. The GOJ wants to reduce or completely eliminate their contribution to USFJ utilities (but keep their support of other areas like labor). The UCS currently provides almost two-thirds of the USFJ utility bills, so the cost of energy may go up significantly in the near future. Installation of renewable energy projects could help relieve some of that escalation. 


\section{Economic Evaluation of OCONUS Renewable Projects}

The goal of the renewable energy assessment is to generate an inventory of renewable energy resource options, which will then be evaluated with appropriate economic scenarios and compared with regulatory and legal issues to determine the best path forward. The economic feasibility of each potential project will be determined through a life cycle cost analysis, similar to the methods used for US installations. These analyses take project-specific data (capital costs, O\&M costs, technology performance, and equipment life) and apply location-specific data (taxes, incentives, and cost multipliers). The project-specific data will not change with location, but Japanese taxes, incentives, and costs relative to US costs must be understood for this assessment.

\section{Incentives and Other Parameters}

Projects analyzed here will use the Japanese tax system in the economic assessments. As part of the UCS, GOJ pays the labor cost for Japanese citizens to work at US military installations. In addition, all new construction projects are funded by GOJ through the Facility Improvement Program. As a result, only Japanese contractors, not US contractors, are utilized for construction on US installations in Japan, and all portions of a project will be subject to Japanese law.

Corporate taxes in Japan are levied for 5 different areas: the national tax, inhabitant tax or local tax, enterprise tax, municipal taxes, and special local taxes. The national tax is $30 \%$ for incomes over ¥8 million. Inhabitant taxes are based on the number of workers an entity employs, and will be ignored in this preliminary feasibility assessment. The enterprise tax is $7.56 \%$ for over $¥ 100$ million in paid-in capital (which projects analyzed in this assessment are assumed to exceed) and over $¥ 8$ million in income. There is an additional $0.21 \%$ tax on paid-in capital and a surcharge of $0.504 \%$ on total added value, for a total national corporate tax rate of $38.1 \%$. Prefecture taxes range from $5 \%$ to $6 \%$, and are assumed in this assessment to be $5.3 \%$. Special local taxes are indicated at $4.3 \%$. Thus, income taxes at all levels are $47.7 \%$, excluding inhabitant taxes (JETRO 2010, JETRO 2007, taxrate.cc 2009).

In addition, Japan has a 5\% consumption tax, which appears to be similar to US sales and use taxes. This is based on a $4 \%$ national rate and a $1 \%$ local rate. Japan also has ownership, or property, taxes which amount to $1.7 \%$ between a direct $1.4 \%$ and a city planning surcharge of 0.3\% (JETRO 2010, JETRO 2007, taxrate.cc 2009).

Because GOJ already pays most of the USFJ utility bill, no additional incentives are offered for renewable energy projects built on US land. For instance, the subsidies and tax breaks offered for PV generation are not available to USFJ. However, there are two policies that could lower renewable energy costs for the US Army: a PV buyback program and renewable energy credit (REC) sales.

GOJ implemented a buyback program on November 1, 2009 for PV electricity generation. For businesses and non-residential buildings, excess electricity generation can be sold back to the utility at a rate of $¥ 24 / \mathrm{kWh}$ (about $24 థ / \mathrm{kWh}$ ), up to $500 \mathrm{~kW}$. For residential buildings, excess

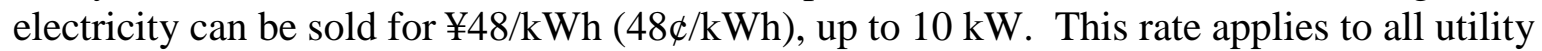
customers in Japan; all customers (including USFJ) are also charged an extra ¥0.01/kWh on their electricity consumption to pay for the incentive program. The buyback rates will be reduced each year (and eliminated after 10 years) as more PV is installed and capital costs continue to 
drop. The size of the reduction will be decided each year (Energy Conservation and Renewable Energy Department 2009).

Japan's renewable portfolio standard (RPS) requires utilities to provide a certain percentage of renewable energy as part of their portfolio. Renewable projects, regardless of the owner or power purchaser, generate RECs that can be sold to utilities to help them meet RPS requirements. REC sales could bring down the cost of energy for USFJ projects.

To apply the CONUS methodology to OCONUS locations, an adjustment must be made to the costs so that they are accurate for the location being analyzed. In PNNL's FY09 FEDS assessment of Camp Zama area installations (Kora et al. 2010), a factor of 1.31 was used as a global multiplier to adjust project costs from US levels to Japanese levels. In accordance with advice from Camp Zama personnel, that factor is still valid and was used for this assessment as well.

\section{Approach}

In assessing the economic feasibility of renewable energy projects at CONUS installations, PNNL generally evaluates two business case alternatives: (1) investment by an independent power producer (IPP), and (2) Energy Conservation Investment Program (ECIP) funding. These two funding sources have the best returns on Federal investments among the available alternatives. Two other alternatives are examined when conditions are favorable: (3) the Utility Energy Services Contract (UESC), and (4) the Energy Savings Performance Contract (ESPC).

Under an IPP scenario, an independent power producer will generally fund, construct, and operate a renewable energy facility, selling power into the competitive marketplace and/or directly to the site that hosts the energy project. This scenario is generally economic when the third party investor can take advantage of substantial Federal and state incentives. The incentives depend on the type of renewable energy generated and may include production tax credits, investment tax credits, substantially accelerated tax depreciation of assets, reductions in sales taxes, and exemption from property tax.

The minimum after-tax internal rate of return (IRR) used in the analysis of IPP opportunities is $10 \%$. The typical after-tax rate of return for most third party developers is closer to $15 \%$, but there appears to be a suite of renewable energy developers willing to accept a lower return. Both costs and prices are assumed to escalate with an inflation rate of $1.2 \%$.

ECIP is one standard DoD approach for making energy efficiency and renewable energy investments using Federally appropriated funding. ECIP investment awards are made based upon savings to investment ratio (SIR) and simple payback criteria. ECIP funding is limited, and is awarded on a competitive basis within the Army-only the most economic projects can be assured funding. The approach used in the analyses follows the Federal life cycle cost (LCC) methodology and procedures in 10 CFR, Part 436, Subpart A. The LCC calculations are based on the Federal Energy Management Program (FEMP) discount rates and energy price escalation rates updated on April 1, 2009. 
The assumptions for ECIP are driven by FEMP. Table 2 lays out the discount rates underlying the model as of April 2008. The real and nominal rates for DOE/FEMP imply a 1.2\% inflation rate. New discount rates were obtained from Rushing and Lippiatt (2009).

Table 2: Discount Rate Assumptions in ECIP Model

\begin{tabular}{|r|c|c|c|c|c|c||}
\hline \hline Discount Rate & DOE FEMP & OMB 3-year & OMB 5-year & OMB 7-year & OMB 10-year & OMB 30-year \\
\hline Real & $3.0 \%$ & $2.1 \%$ & $2.3 \%$ & $2.4 \%$ & $2.6 \%$ & $2.8 \%$ \\
\hline Nominal & $4.2 \%$ & $3.3 \%$ & $3.5 \%$ & $3.6 \%$ & $3.8 \%$ & $4.0 \%$ \\
\hline
\end{tabular}

The UESC and ESPC are very similar approaches, where a third party invests in an energy project on the Federal facility in return for a share of the energy savings that result. The major difference is that under an UESC, the third party is a utility - generally the utility providing energy to the Federal facility. Under an ESPC, the investment party is a non-utility, generally an engineering firm that specializes in energy projects. Under UESC and ESPC, the third party must be repaid out of each year's operational dollars, and the investment must be repaid within the lifetime of the asset. Generally in the US, UESC is more feasible than ESPC because utilities can obtain capital less expensively than can the ESPC contractor. But not all utilities fund UESC projects and the types of projects funded may be limited, which opens the door for ESPC. The UESC/ESPC cannot generally capture depreciation or tax incentives that would be afforded an IPP.

OCONUS installations have access to ECIP funds, but it is unclear if an IPP, UESC, or ESPC would be feasible options in Japan. An IPP would have to compete with the monopolistic utilities, who also own the distribution lines. A UESC would likely be illegal according to US law, because the Japanese standard way of business is to partner with friends and family instead of using competitive contracts. An ESPC is possible in Japan but not an attractive option - the Navy entered into an ESPC in Japan but is now trying to terminate it.

Specific contracting, cultural, and legal issues will need to be explored and resolved as part of the implementation of promising projects. For this effort, the economic cases presented under the ECIP, IPP, and UESC/ESPC assumptions will be sufficient to determine which projects are worth pursuing within a range of options.

\section{FATE2-P Model Description}

The FATE2-P (Financial Analysis Tool for Electric Energy Projects) financial analysis model is used to evaluate the feasibility of renewable energy projects. The spreadsheet model was developed by Princeton Economic Research, Inc. and the National Renewable Energy Laboratory for the US Department of Energy. FATE2-P can be used to develop pro forma financial statements for a utility using a revenue requirements approach or for an IPP using the discounted rate of return approach. Both approaches are diagrammed in Figure 3. Other models produce very similar results given the same inputs. The revenue requirements approach follows a cost-based utility revenue requirements analysis, and the IPP approach uses a market-based discounted cash flow return. The FATE2-P model has been updated by PNNL to include the military construction (MILCON) ECIP module in addition to the rate of return methodology. The model has been used to model improved technology designs, resource variability, and favorable tax treatment on renewable energy products. The advantage this model has over other 
models is that it is already suited for handling all of the renewable energy technologies in this study (except GSHPs) through one model, thus providing results on a comparable basis across all technologies.
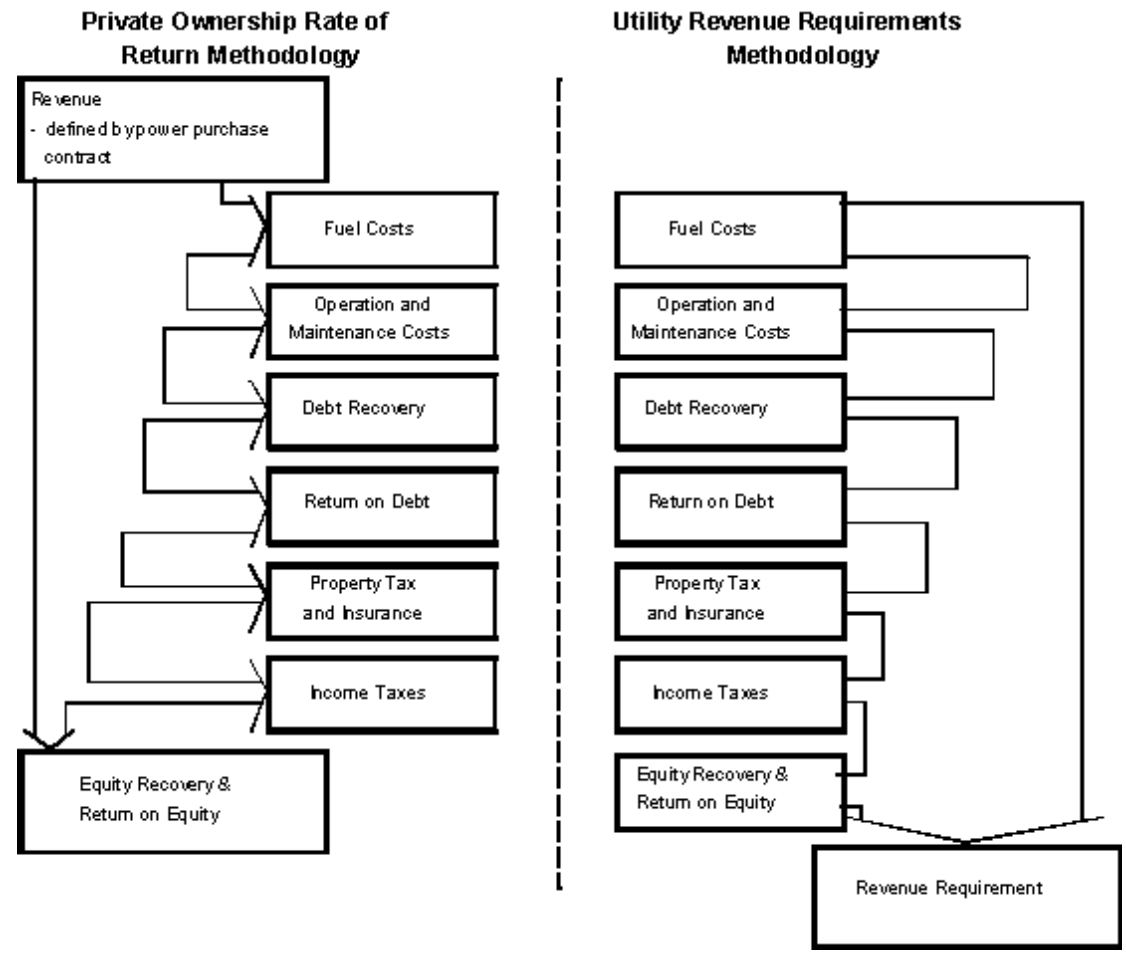

Figure 3: FATE2-P Methodology

\section{Facility Energy Decision System (FEDS) Model}

FEDS is a building energy modeling software developed by PNNL to support the economic analysis of efficiency technologies at large, multi-building sites. Building characteristics are entered into the model using as much detail as possible, and the model uses the given information to make inferences for the remaining characteristics. Multiple sets of building data can be entered into the same model, so that an entire site can be represented at once. The optimization cycle uses data about the location of the site and the energy prices entered into the model to determine cost-effective retrofits for each set of building data, and to calculate costs and savings. The suggested retrofits can range from lighting to building envelope to HVAC, covering all aspects of a building's energy use and considering interactive effects. In addition, the model can be adjusted to consider just one type of retrofit. In these renewable energy analyses, GSHPs are the only technology analyzed. 


\section{Methodologies by Resource}

The options analyzed in this assessment will include potential on-site generation resources (including wind, solar, geothermal, and biomass/waste), potential near-site resources where a renewable fuel (biomass or waste) could be provided to the site or power could be provided "over the fence," and potential building-level applications of GSHPs. For CONUS assessments, the focus is on resources that might produce larger amounts of electricity (1 MW or more). In Japan, this requirement may be relaxed somewhat because the local emphasis is on smaller-scale renewable resources and the installations are small with lower electric demands.

\section{Solar}

\section{Background}

\section{Solar Technology}

Solar energy is typically used for electricity generation, space heating, and water heating through PV and solar thermal power systems. This analysis focuses on electricity generation from PV power systems.

There are three typical PV module mounting configurations. The first is to mount the modules on the ground so that the panels are south-facing and tilted at an angle equal to the latitude. This angle helps optimize electricity generation. The second strategy is to mount the modules flush on building rooftops. This strategy allows for more efficient land use, and the mounting brackets require less capital than ground mounts. However, the modules must be tilted at approximately the same angle as the roof, which may lead to suboptimal electricity production. The final strategy is to mount the modules on assemblies that can track the sun. This strategy allows systems to maximize their electricity generation; however, these systems must be groundmounted and have higher capital costs.

As a world leader in PV manufacturing, Japan is home to many recognizable PV manufacturing companies such as Sharp, Kyocera, Sanyo Electric, Mitsubishi Electric, and Kaneka (Foster 2005), and Japan accounts for $17 \%$ of the world's PV production (Solarbuzz 2009). Most of the modules from these manufactures are destined for overseas customers.

However, substantial quantities of PV modules are needed to satisfy a strong domestic demand. Unlike the US (and to a lesser extent the EU), the vast majority of Japan's PV capacity has been installed on residential homes, not on commercial lands owned by utilities or specialty PV firms. This is not surprising, as the Japanese government has set a goal of two-thirds of all new homes equipped with a PV system by 2020 (Siegel 2010). Typical residential arrays are between 2 and $5 \mathrm{~kW}$.

\section{Obstacles to Development in Japan}

Although the high cost of electricity and a promising solar resource encourages PV development, typhoons are frequently cited as a major concern for PV panels (Foster 2005). Consequently, roof-mounted PV systems are often installed at angles that help reduce their risk to high winds, at the sacrifice of optimal energy production. However, fears over typhoons have also 
encouraged a high level of metal roof installation, which is an ideal roof type for PV module mounting.

Another potential obstacle for large-scale PV deployment in Japan is the current and historical lack of large-scale PV array construction. PV deployment is highly focused on residential systems and there are relatively few large arrays. Therefore, the construction of large arrays and axis-tracking systems may be more challenging (though not impossible) in Japan because of a limited number of experienced contractors.

Lastly, the Japanese PV market has been overwhelmingly dominated by silicon-based systems because of political concerns over toxic metals (Foster 2005). Consequently, thin film systems such as CdTe (cadmium telluride) and potentially CIGS (copper indium gallium selenide) may not be able to be installed, limiting PV options.

\section{PV Projects in Japan}

About 92\% of installed PV systems in Japan are grid-connected distributed generation applications on residential and public buildings (Foster 2005). Table 3 lists the major PV power plants and national capacities.

Table 3: PV Energy Projects in Japan (Lenardic 2010)

\begin{tabular}{||l|c|c|}
\hline \multicolumn{1}{|c|}{ Project } & Location & Capacity \\
\hline Sharp Factory Roof & $\begin{array}{c}\text { Kameyama } \\
\text { (Central Japan, near Nagoya) }\end{array}$ & $5.2 \mathrm{MW}$ \\
\hline Wakkanani City Project & $\begin{array}{c}\text { Wakkanai } \\
\text { (Northern Japan, Hokkaido) }\end{array}$ & $5.0 \mathrm{MW}$ \\
\hline Ota City Project & $\begin{array}{c}\text { Ota City } \\
\text { (Central Japan, near Tokyo) }\end{array}$ & $2.1 \mathrm{MW}$ \\
\hline Hokuto Project & $\begin{array}{c}\text { Hokuto } \\
\text { (Central Japan, near Tokyo) }\end{array}$ & $2.0 \mathrm{MW}$ \\
\hline Kiyota & $\begin{array}{c}\text { Sapporo } \\
\text { (Northern Japan, Hokkadio) }\end{array}$ & $1.5 \mathrm{MW}$ \\
\hline $\begin{array}{l}\text { Sanyo Solar Ark } \\
\text { (Central Japan, near Nagoya) }\end{array}$ & $630 \mathrm{~kW}$ \\
\hline Various Government Buildings & Downtown Tokyo & $500 \mathrm{~kW}$ \\
\hline \multicolumn{1}{|c|}{ Cumulative Capacities } & Location & Capacity \\
\hline $\begin{array}{l}\text { Cumulative Residential } \\
\text { PV Capacity in 2004 }\end{array}$ & All Japanese Homes & $830 \mathrm{MW}$ \\
\hline $\begin{array}{l}\text { Cumulative PV Capacity in } \\
\text { 2006 (Honda 2007) }\end{array}$ & $\begin{array}{c}\text { All of Japan } \\
\text { Gumulative PV Capacity } \\
\text { Goal for 2030 }\end{array}$ & $1422 \mathrm{MW}$ \\
\hline \hline
\end{tabular}

Japan enjoys relatively low PV module prices and its simplified electrical codes allows for relatively inexpensive system installation. For instance, the average residential PV system in Japan cost about \$6 per watt in 2004 (Foster 2005). A comparable system in the US would have likely cost over \$8 per watt (33\% more) in the US in 2004 (Solarbuzz 2009, LBNL 2009). 


\section{Data Sources}

The data used to analyze the solar resource at US IMCOM installations is also available for OCONUS installations. For CONUS renewable assessments, PNNL gathers solar resource and PV performance data from the following.

- NASA’s Surface Meteorology and Solar Energy (SSE) database, http://eosweb.larc.nasa.gov/sse/

- $\quad$ RETScreen ${ }^{\circledR}$ International, http://www.retscreen.net, a project analysis software package developed by Natural Resources Canada that allows a user to simulate the performance of several PV systems configurations

\section{Approach}

Because the same resources are available for both CONUS and OCONUS solar assessments, the same approach will be used. The listed data sources will be used to calculate the site's yearly average insolation values (i.e., the quantity of sunlight that strikes a surface), and then the electrical output of a 1-MW power plant for three different cases: single-axis tracking, flush roof-mounted, and latitude-tilted ground-mounted. Each of these three cases assumes a typical monocrystalline silicon module is used. Modules with the specifications listed in Table 4 are common from many suppliers around the world.

Table 4: PV Module and System Specifications

\begin{tabular}{||l|c||}
\hline \multicolumn{1}{|c||}{ Parameter } & Value \\
\hline Module Material & Monocrystalline Silicone \\
\hline Module Efficiency, \% & 19 \\
\hline Temperature Coefficient, \%/ ${ }^{\circ} \mathrm{C}$ & 0.4 \\
\hline Area per kW, sf (m ${ }^{2}$ ) & $21(2)$ \\
\hline Panel Interspacing Area, sf per panel & $4-75$ \\
\hline Inverter Efficiency, \% & (depending on module mounting) \\
\hline Miscellaneous PV Array Losses (due to dirt, snow, detritus, etc.), \% & 50 \\
\hline \hline
\end{tabular}

After the solar resource characterization and array energy output calculation, the next step is siting consideration. One of the primary siting considerations is proximity to transmission lines. When possible, existing on-site interconnection and transmission capacity and availability will be evaluated. Available land is another siting concern because multi-megawatt PV arrays can occupy over 1 acre (over 5,000 $\mathrm{m}^{2}$ ) of land. Land without shading from structures, vegetation, or other large objects is needed for PV arrays. 


\section{Wind}

\section{Background}

\section{Wind Technology}

Wind turbines come in many different sizes and configurations. The industry standard wind turbine employs the Danish configuration - a horizontal-axis, three-bladed rotor, an upwind orientation, and an active yaw system to keep the rotor oriented into the wind.

Turbines for bulk power production tend to be $660 \mathrm{~kW}$ to $3 \mathrm{MW}$ in size. Hub heights can range from 50 meters (164 feet) to 80 meters (262 feet), and sometimes more. Turbines for consumer and remote grid production are found in the range of $50 \mathrm{~kW}$ to $250 \mathrm{~kW}$. Hub heights range between 25 meters ( 80 feet) and 40 meters (131 feet). Residential-scale wind turbines are used for remote power, battery charging, or net-metering generation. These turbines tend to be 400 watts to $50 \mathrm{~kW}$. For turbines greater than $1 \mathrm{~kW}$, the hub heights range from 12 meters (40 feet) to 36 meters (120 feet).

Japan has four wind turbine manufacturers: Mitsubishi Heavy Industry (MHI), Fuji Heavy Industry, Japan Steel Works, and Komai Tekko (GWEC 2009). As of 2006, these manufacturers collectively accounted for $14 \%$ of the domestic market (Nakata 2008). Foreign manufacturers such as Vestas, General Electric, and Enercon currently dominate the Japanese market. And while MHI continues to manufacture turbines in Japan, it has stopped selling its turbines in Japan (GWEC 2009).

\section{Obstacles to Development in Japan}

While there is a strong wind resource in Japan, wind energy project development has encountered a number of obstacles in recent years. These obstacles include extreme weather, a difficult permitting process, grid constraints, and a recovering global economy (GWEC 2009).

Japan, as an island nation, experiences typhoons, strong wind gusts, and high wind turbulence. A number of wind turbines have been severely damaged from extreme weather conditions. In 2003, a strong typhoon broke five wind turbines on Okinawa's Miyako Island. Wind speeds reached more than $252 \mathrm{kph}$ (157 mph) (Nakata 2008). To address this problem, various Japanese agencies are working together to develop design and safety standards for turbines operating in Japan that go beyond what is required by the International Electrotechnical Commission (IEC).

A new Japanese building code in 2007 temporarily halted wind energy project activities as developers had to learn how to navigate through the new permitting process. Since the initial code implementation, the process has become more standardized and projects are again being built.

The limits of the Japanese grid system and the unwillingness of the monopolistic regional electricity companies to address the issue of grid constraint are additional barriers to development. The best wind resources in Japan are located in the north and south ends of the country, and the north end of Japan is also out of the path of most typhoons, but the load centers are primarily in the center of Japan.

Renewable Energy Assessment Methodology for Japanese OCONUS Army Installations 
As the global economy continues to recover, wind energy project development in Japan and elsewhere is expected to rebound.

\section{Japanese Market Forces}

The Japan Natural Energy Company (JNEC) provides green power certificates from wind energy generation projects to corporate customers. The customer receives a "Certification of Green Power" in return for its $¥ 4 / \mathrm{kWh}$ payments to support the creation of wind energy projects. The power generated is sold to regional electric power companies (JNEC 2001, JNEC 2003).

Incentives available for wind project development include government subsidies (i.e., the Field Test and New Energy Business Support Programs), and higher prices paid for the output from renewable plants. The government has set the goal of having 3,000 MW of wind power in Japan by 2010 (GWEC 2009). While that target could be reached eventually, it is unlikely to happen quickly given the obstacles described.

\section{Wind Energy Projects in Japan}

According to the Global Wind Energy Council (GWEC), Japan has the wind resource to support an installed capacity of 1.5 gigawatts (2009). There are around 1,400 wind turbines currently installed in Japan (Nakata 2008). Japan's total installed capacity has grown from $136 \mathrm{MW}$ in 2000 to 1,880 MW in 2008. A sample of projects is listed in Table 5.

Table 5: Wind Energy Projects in Japan

\begin{tabular}{|c|c|c|c|}
\hline Name & Location & Project Size & $\begin{array}{c}\text { Project Energy } \\
\text { Generation }\end{array}$ \\
\hline Nagashima Wind Hill $^{1}$ & $\begin{array}{l}\text { Kagoshima Prefecture } \\
\text { (southern tip of Japan) }\end{array}$ & $\begin{array}{l}\text { 50.4 MW, } 21 \mathrm{MHI} \\
\text { turbines }\end{array}$ & $100,000 \mathrm{MWh} / \mathrm{yr}$ \\
\hline $\begin{array}{l}\text { Hibikinada Wind } \\
\text { Farm }^{2}\end{array}$ & $\begin{array}{l}\text { Hibikinada (south end } \\
\text { of Japan) }\end{array}$ & $\begin{array}{l}15 \mathrm{MW}, 10 \mathrm{GE} \\
\text { turbines }\end{array}$ & $35,000 \mathrm{MWh} / \mathrm{yr}$ \\
\hline Choshi Wind Project $^{3}$ & $\begin{array}{l}\text { Chiba Prefecture } \\
\text { (outside of Tokyo, on } \\
\text { eastern shore) }\end{array}$ & $\begin{array}{l}25.5 \mathrm{MW}, 17 \mathrm{GE} \\
\text { turbines }\end{array}$ & Not available \\
\hline $\begin{array}{l}\text { Gushikawa Power } \\
\text { Station }^{4}\end{array}$ & Okinawa Island & $\begin{array}{l}2 \mathrm{MW}, 1 \mathrm{MHI} \\
\text { turbine }\end{array}$ & Not available \\
\hline
\end{tabular}

\section{Data Sources}

Data sources available for wind assessments in Japan are similar to what is used for assessments in the US. The wind assessment methodology relies on the resources listed in Table 6.

Table 6: Wind Data Resources for Japan

\begin{tabular}{|l|l|}
\hline \multicolumn{1}{|c|}{ Resource } & \multicolumn{1}{c|}{ Website } \\
\hline 3TIER's FirstLook & $\underline{\text { http://firstlook.3tier.com/ }}$ \\
\hline NASA SSE data & $\underline{\text { http://eosweb.larc.nasa.gov/cgi-bin/sse/grid.cgi?email= }}$ \\
\hline NEDO Japan Wind Resource Map & $\underline{\text { http://app2.infoc.nedo.go.jp/nedo/ }}$ \\
\hline \hline
\end{tabular}


3TIER's FirstLook is an online wind resource tool. It uses Google maps to allow a user to click on a specific location (or provide coordinates) to learn the location's average, annual wind speed at hub heights of $20 \mathrm{~m}(65 \mathrm{ft}), 50 \mathrm{~m}(164 \mathrm{ft})$, and $80 \mathrm{~m}(262 \mathrm{ft})$.

NASA Surface Meteorology and Solar Energy (SSE) provides data collected over a 10-year period from July 1983 to June 1993 on a $1^{\circ}$ by $1^{\circ}$ grid system. The average wind speed provided for this large amount of land is somewhat useful for an area with little to no terrain variation, but it is not as useful when examining a site located in a mountainous area, for example. Therefore this data source will be used as a point of reference.

US wind resource maps first developed by PNNL in 1987 have been updated and validated over the years by the National Renewable Energy Laboratory (NREL), DOE, and the private company AWS Truewind. The most current maps can be found at www.windpoweringamerica.gov. These maps only cover the US.

A similar wind resource map classification scheme is available for Japan. The New Energy and Industrial Technology Development Organization (NEDO) published a Wind Energy Map and the Local Area Wind Energy Prediction System (LAWEPS) in 2005. The NEDO map is colorcoded based on the average wind speed found at any given location in $0.5 \mathrm{~m} / \mathrm{s}$ increments and provides wind speed information at hub heights of $30 \mathrm{~m}$ (98 ft), $50 \mathrm{~m}(164 \mathrm{ft})$, and $70 \mathrm{~m}(230 \mathrm{ft})$.

These three sources of wind data, 3TIER's FirstLook tool, NEDO’s Wind Energy Map, and NASA SSE data, will be consulted to construct a wind resource characterization for each Japanese installation evaluated.

\section{Approach}

Because the data sources are similar for CONUS and Japanese wind energy assessments, the approaches will also be similar. To prepare for the economic analysis of wind projects at Camp Zama and other Japanese installations, the wind resource availability at each location must first be determined. PNNL will use publicly available information from 3TIER's FirstLook wind mapping tool, NEDO’s Wind Energy Map, and NASA SSE data.

According to industry standards developed as part of the Wind Energy Resource Atlas of the United States, there are seven main classes of wind power, as defined in Table 7 (PNL and NREL 1986). Wind power class definitions are a convenient benchmarking tool. A strong Class 3 resource, preferably Class 4, is generally required to achieve an economic project on a large, commercial scale. 
Table 7: Classes of Wind Power Density at $50 \mathrm{~m}$

\begin{tabular}{|c|l|l||}
\hline $\begin{array}{c}\text { Wind Power } \\
\text { Class }\end{array}$ & $\begin{array}{c}\text { Wind Power } \\
\text { Density, } \\
\text { W/m } \mathbf{m}^{2}\end{array}$ & \multicolumn{1}{|c|}{ Speed, m/s (mph) } \\
\hline 1 & $<200$ & $<5.6(12.5)$ \\
\hline 2 & $200-300$ & $5.6(12.5)-6.4(14.3)$ \\
\hline 3 & $300-400$ & $6.4(14.3)-7.0(15.7)$ \\
\hline 4 & $400-500$ & $7.0(15.7)-7.5(16.8)$ \\
\hline 5 & $500-600$ & $7.5(16.8)-8.0(17.9)$ \\
\hline 6 & $600-800$ & $8.0(17.9)-8.8(19.7)$ \\
\hline 7 & $>800$ & $>8.8(19.7)$ \\
\hline
\end{tabular}

The NEDO Japan wind resource map color-coding scheme (by each $0.5 \mathrm{~m} / \mathrm{s}$ (1.1 mph) wind speed increment) can easily be translated to wind power classes. Referencing the wind resource map and labeling a site with a wind power class rating provides a point of reference to the wind speed information provided by the 3TIER tool and the NASA SSE data. From these data sources, a site-specific average wind speed will be selected for use in the project size calculations, which in turn are needed for the economic analysis. The cost of energy and the consistency of the wind resource can play a significant role in determining the economics of a wind project.

Once the wind resource characterization has been established, the next step is to evaluate siting issues. The primary siting consideration is access to transmission lines for interconnection and delivery of energy. To the extent possible, existing on-site interconnection and transmission capacity and availability will be evaluated. Available land is another siting concern. Land is needed for turbines without interference from other tall structures, and with enough space between turbines to not cause wake interference with each other. Turbines must be carefully located to ensure avoidance of interference with aircraft, radar, mission impacts, or environmental considerations. Local wind developer activity in the area is an indication of interest in wind energy and of project potential. If there are any existing projects and development activities in the area of the installation, this will be included in the assessment.

Finally, using the performance capabilities of a 1.5-MW turbine and the annual average wind speed identified by the resource availability assessment, the capacity factor for a potential project at each installation is determined.

A GE 1.5sl wind turbine is used for the capacity factor calculations for two main reasons. First, GE is a dominant market player in both the US and Japan. GE turbines accounted for $45 \%$ of the US market share in 2009 (Siegel 2009) and 21\% of the Japanese market as of 2006 (Nakata 2008). Second, the standard conditions power curve for the turbine is publicly available and therefore readily accessible for use in the preliminary capacity factor calculations. The capacity factor is in turn used in the economic analysis. 


\section{Biomass and Waste-to-Energy}

\section{Background}

\section{Biomass Technology and Current Utilization}

The term "biomass" refers to renewable fuels used for power production that include agricultural waste, forest and wood processing waste, animal waste, industrial waste, dedicated biomass crops, and methane from landfills and wastewater treatment plants. Biomass power, fuel, or heat production is classified as "new energy," along with other renewable energy sources, by the Japanese Agency for Natural Resources and Energy. Japan has a goal of increasing biomass power production from approximately 2,010 MW (FY05) to 4,500 MW in FY10 (Agency for Natural Resources and Energy 2008).

The primary technologies for producing electricity rely upon steam turbines, gas turbines, or combined cycle turbine generators. Generators are energized by steam produced from direct combustion of raw material, or a synthetic gas (syngas) produced through anaerobic digestion or gasification. Direct combustion and anaerobic digestion technologies are mature and have been proven commercially. Gasification technologies are newer in the market, but are promising based on a number of successful installations. Anaerobic digestion is widely used, but primarily for smaller applications in rural and municipal projects rather than large commercial installations.

Biomass can also be added to replace a fraction of coal used in an existing combustion or gasification plant. Co-firing is a common practice with minimal capital cost involved, compared to stand-alone biomass or WTE systems.

Table 8 lists example projects in Japan that utilize biomass resources as a feedstock.

Table 8: Example Biomass Energy Projects in Japan

\begin{tabular}{||l|l|l|c|l||}
\hline \multicolumn{1}{|c|}{ Name } & \multicolumn{1}{|c|}{ Location } & \multicolumn{1}{|c||}{ Feedstock / Technology } & $\begin{array}{c}\text { Biomass Consumption } \\
\text { (tons/yr) }\end{array}$ & $\begin{array}{c}\text { Project } \\
\text { Capacity }\end{array}$ \\
\hline $\begin{array}{l}\text { Chugoku Electric } \\
\text { Power Co. (Misumi } \\
\text { Power Station) }\end{array}$ & $\begin{array}{l}\text { Hamada City, Shimane } \\
\text { Prefecture }\end{array}$ & $\begin{array}{l}\text { Woody biomass / Coal co- } \\
\text { firing demonstration project }\end{array}$ & $\begin{array}{l}30,000 \\
\text { (combined } \\
\text { output) }\end{array}$ \\
\hline $\begin{array}{l}\text { Tokyo Electric } \\
\text { Power Company } \\
\left(\begin{array}{l}\text { Hitachi-Naka } \\
\text { Power Station) }\end{array}\right.\end{array}$ & $\begin{array}{l}\text { Naka, Ibaraki } \\
\text { Prefecture }\end{array}$ & $\begin{array}{l}\text { Planned woody biomass / } \\
\text { Coal co-firing project }\end{array}$ & 70,000 & $\begin{array}{l}1,000 \mathrm{MW} \\
\text { (combined } \\
\text { output) }\end{array}$ \\
\hline $\begin{array}{l}\text { Asahi Kasei NS } \\
\text { Energy Corporation }\end{array}$ & $\begin{array}{l}\text { Nobeoka, Miyazaki } \\
\text { Prefecture }\end{array}$ & $\begin{array}{l}\text { Woody biomass / Coal co- } \\
\text { firing project }\end{array}$ & 10,000 & $50 \mathrm{MW}$ \\
\hline $\begin{array}{l}\text { Yamagata Green } \\
\text { Power }\end{array}$ & $\begin{array}{l}\text { Murayama City, } \\
\text { Yamagata Prefecture }\end{array}$ & $\begin{array}{l}\text { Wood chips / Gasification } \\
\text { project }\end{array}$ & 22,000 & $2 \mathrm{MW}$ \\
\hline
\end{tabular}

(Asia Biomass Office 2010)

2 (Asahi Kasei 2008)

3 (Koch 2008)

Sumimoto Heavy Industries, Ltd., IHI Corporation, EBARA Corporation, and Takuda Co., Ltd. are among the main manufacturers of biomass and waste power generation and gasification plants. Foreign manufacturers also make up a portion of the market, as evident by the GE gas 
engines currently utilized in one of Japan's largest wood gas-to-energy facilities located in Murayama, Yamagata (GE Energy 2008).

\section{Waste-to-Energy Technology and Current Utilization}

Waste-to-energy (WTE) is similar to biomass, but uses municipal solid waste (MSW) as a fuel source. It is also considered "renewable" by the Japanese RPS (GWEA 2009). Combustion and gasification technologies, in combination with turbines, can be used with MSW as a feedstock. Due to limited land availability for landfills, incineration (combustion) is the most common method for waste disposal in Japan. According to the Ministry of the Environment, in FY 2006 there were 1,301 waste incineration facilities nationwide. About $70 \%$ of all waste incineration facilities used heat recovery for steam, electric power generation, or other uses. Total nationwide capacity was 1,590 MW with a total power generation of 7,190 GWh (MOE 2009). Efficiency in these facilities range from a few percent to over $20 \%$.

\section{Data Sources}

For CONUS Army installations, the US Department of Agriculture (USDA) National Agricultural Statistics Service, the USDA Forest Service, the Environmental Protection Agency (EPA), and various local state, county, and municipality websites are typical references from which statistics can be compiled on feedstock availability. Similar resources exist for biomass feedstocks in Japan. These resources are listed in Table 9, along with notes on the type of relevant feedstock statistics available. 
Table 9: Japan Feedstock Resources

\begin{tabular}{|c|c|c|c|}
\hline Data Type & Reference & Notes & Website \\
\hline \multirow[t]{5}{*}{$\begin{array}{l}\text { Waste } \\
\text { disposal and } \\
\text { recycling data }\end{array}$} & $\begin{array}{l}\text { Japan Ministry of } \\
\text { the Environment } \\
\text { (MOE) }\end{array}$ & $\begin{array}{l}\text { - Statistics, policy, standards, and reports } \\
\text { available in English on a variety of } \\
\text { topics including greenhouse gases, } \\
\text { waste and recycling. } \\
\text { - Higher level reports, but useful for } \\
\text { background information on energy } \\
\text { policy in Japan. }\end{array}$ & http://www.env.go.jp/en/ \\
\hline & \begin{tabular}{|l|} 
Japan Ministry of \\
Economy, Trade and \\
Industry (METI)
\end{tabular} & $\begin{array}{l}\text { - Resource for current energy policies and } \\
\text { incentives } \\
\text { - Some national recycling policy statistics }\end{array}$ & http://www.meti.go.jp/english/ \\
\hline & \begin{tabular}{|l} 
Kanagawa \\
Prefectural \\
Government
\end{tabular} & $\begin{array}{l}\text { - Translated prefectural MSW statistics } \\
\text { provided by Camp Zama personnel }\end{array}$ & $\begin{array}{l}\text { www.pref.kanagawa.jp/osirase/ko } \\
\text { kusai/tagengo/index.html }\end{array}$ \\
\hline & \begin{tabular}{|l} 
Hiroshima \\
Prefectural \\
Government
\end{tabular} & $\begin{array}{l}\text { - Translated prefectural MSW statistics } \\
\text { provided by Camp Zama personnel }\end{array}$ & http://www.pref.hiroshima.lg.jp/ \\
\hline & $\begin{array}{l}\text { Okinawa Prefectural } \\
\text { Government }\end{array}$ & $\begin{array}{l}\text { - Translated prefectural MSW statistics } \\
\text { provided by Camp Zama personnel }\end{array}$ & $\begin{array}{l}\text { http://www.pref.okinawa.jp/index } \\
\text { html }\end{array}$ \\
\hline \begin{tabular}{|l} 
Wheat and \\
other crop \\
residue data
\end{tabular} & $\begin{array}{l}\text { Japan Ministry of } \\
\text { Agriculture, } \\
\text { Forestry, and } \\
\text { Fisheries } \\
\end{array}$ & - Prefectural statistics by type of crop & $\begin{array}{l}\text { http://www.maff.go.jp/e/index.ht } \\
\underline{\text { ml }}\end{array}$ \\
\hline \multirow[t]{4}{*}{ Forestry data } & \begin{tabular}{|l} 
Japan Ministry of \\
Agriculture, \\
Forestry, and \\
Fisheries \\
\end{tabular} & $\begin{array}{l}\text { - Annual Report on Trends in Forest and } \\
\text { Forestry offers nationwide statistics } \\
\text { (MAFF 2009) }\end{array}$ & $\begin{array}{l}\text { http://www.maff.go.jp/e/index.ht } \\
\underline{\mathrm{ml}}\end{array}$ \\
\hline & \begin{tabular}{|l|} 
Kanagawa \\
Prefectural \\
Government \\
\end{tabular} & $\begin{array}{l}\text { - Translated prefectural forestry statistics } \\
\text { provided by Camp Zama personnel }\end{array}$ & $\begin{array}{l}\text { www.pref.kanagawa.jp/osirase/ko } \\
\text { kusai/tagengo/index.html }\end{array}$ \\
\hline & \begin{tabular}{|l|} 
Hiroshima \\
Prefectural \\
Government \\
\end{tabular} & $\begin{array}{l}\text { - Translated prefectural forestry statistics } \\
\text { provided by Camp Zama personnel }\end{array}$ & http://www.pref.hiroshima.lg.jp/ \\
\hline & $\begin{array}{l}\text { Okinawa Prefectural } \\
\text { Government }\end{array}$ & \begin{tabular}{|l} 
- Translated prefectural forestry statistics \\
provided by Camp Zama personnel
\end{tabular} & $\begin{array}{l}\text { http://www.pref.okinawa.jp/index } \\
\text {.html }\end{array}$ \\
\hline \multirow[t]{3}{*}{$\begin{array}{l}\text { Animal waste } \\
\text { data }\end{array}$} & $\begin{array}{l}\text { Kanagawa } \\
\text { Prefectural } \\
\text { Government } \\
\end{array}$ & $\begin{array}{l}\text { - Translated prefectural livestock statistics } \\
\text { provided by Camp Zama personnel }\end{array}$ & $\begin{array}{l}\text { www.pref.kanagawa.jp/osirase/ko } \\
\text { kusai/tagengo/index.html }\end{array}$ \\
\hline & \begin{tabular}{|l} 
Hiroshima \\
Prefectural \\
Government
\end{tabular} & $\begin{array}{l}\text { - Translated prefectural livestock statistics } \\
\text { provided by Camp Zama personnel }\end{array}$ & http://www.pref.hiroshima.lg.jp/ \\
\hline & $\begin{array}{l}\text { Okinawa Prefectural } \\
\text { Government }\end{array}$ & \begin{tabular}{|l} 
- Translated prefectural livestock statistics \\
provided by Camp Zama personnel
\end{tabular} & $\begin{array}{l}\text { http://www.pref.okinawa.jp/index } \\
\text { html }\end{array}$ \\
\hline \begin{tabular}{|l} 
Existing \\
biomass \\
projects
\end{tabular} & Asia Biomass Office & $\begin{array}{l}\text { - Database of articles highlighting } \\
\text { biomass and biofuel projects throughout } \\
\text { Japan }\end{array}$ & $\begin{array}{l}\text { http://www.asiabiomass.jp/englis } \\
\text { h/topics.html }\end{array}$ \\
\hline
\end{tabular}




\section{Approach}

The critical factor in determining feasibility for biomass or waste energy generation is feedstock availability. Due to the small size of the Army installations in Japan, it is unlikely that on-site biomass or waste sources will be sufficient for economic energy production, and a plant would need to be supplemented with off-site resources. Procuring feedstock from off site may or may not be an option because of the political relationship between US military installations and GOJ. Because of this uncertainty surrounding feedstock availability, a breakeven analysis will be completed to determine the amount of feedstock required for an economic plant, using the average energy rates for each site.

Projects will be deemed feasible if electricity can be generated economically with on-site sources of biomass or waste only. Projects will be rated as potentially feasible if feedstock theoretically exists in the prefecture where the installation is located (determined by consulting the references listed in the Data Sources section). Projects requiring more feedstock than is available on-site or in the surrounding area will be rated infeasible.

\section{Geothermal}

\section{Background}

\section{Geothermal Technology}

Geothermal power plants use steam from hot water reservoirs found deep below the Earth's surface. The steam rotates a turbine that activates a generator, producing electricity. There are three commercial types of geothermal power plants used to generate electricity (dry steam, flash steam, and binary cycle), and several newer technologies are entering the marketplace (hot dry rock and engineered geothermal systems). The type of plant depends on the state of the fluid (whether it is steam, hot water, or mixed) and its temperature.

$\checkmark \quad$ Dry Steam power plants use underground steam piped directly from wells to the power plant, where it passes through separators to remove small particles before it is directed into a turbine/generator unit.

$\checkmark$ Flash Steam power plants use geothermal resources that produce high-temperature hot water or a combination of steam and hot water. This very hot water (reservoirs greater than $360^{\circ} \mathrm{F}$ or $182^{\circ} \mathrm{C}$ ) flows up through wells in the ground under its own pressure. As it flows upward and the pressure decreases, some of the hot water boils (flashes) into steam. The steam is then separated from the water and used to power a turbine/generator. Any leftover water and condensed steam are injected back into the reservoir, making this a sustainable resource. Depending on the temperature resource, it may be possible to use a second flash tank, where more steam at a lower pressure is separated for generation (double flash plant).

$\checkmark$ Binary Cycle power plants utilize a secondary fluid in a closed cycle to operate the turbine, instead of direct geothermal steam. These plants operate on water at lower temperatures of about $107-182^{\circ} \mathrm{C}\left(225-360^{\circ} \mathrm{F}\right)$. The heat from the hot water is used to boil a working fluid, usually an organic compound with a low boiling point. The working fluid is vaporized in a heat exchanger and used to turn a turbine, and then 
injected back into the ground to be reheated. The water and the working fluid are kept separated during the whole process, so there is minimal or no contamination. Binary power plants are available at smaller scales of 200 to $1,000 \mathrm{~kW}$.

$\checkmark$ Hot Dry Rock (HDR) geothermal production utilizes high temperature rocks found deep (several kilometers) below the surface by pumping high-pressure water down a borehole into a heat zone. The water captures the heat of the rock by traveling through fractures until it is forced out a second borehole and used to generate electricity. Once the water has cooled, it is pumped back underground to heat up again. This process is most easily utilized in locations with existing cracks or pore spaces.

$\checkmark$ Engineered or Enhanced Geothermal Systems (EGS) are similar to HDR systems. In locations where there are few cracks and connected pore spaces, or little to no cracks or connectivity, cracks can be created or enhanced. The advantage of HDR or EGS is that geothermal resources can be captured for production in non-tectonically active regions. This technology is derived from the oil and gas industry, but is currently very new and expensive for geothermal power production.

\section{Geothermal Energy Projects in Japan}

Japan has nearly 200 volcanoes and associated geothermal energy resources. There are currently 20 geothermal power plants operating in 18 locations nationwide (see Figure 4 and Table 10 below). Total net output from the plants is approximately $535 \mathrm{MW}$, equating to about $0.2 \%$ of Japan’s total power capacity. 


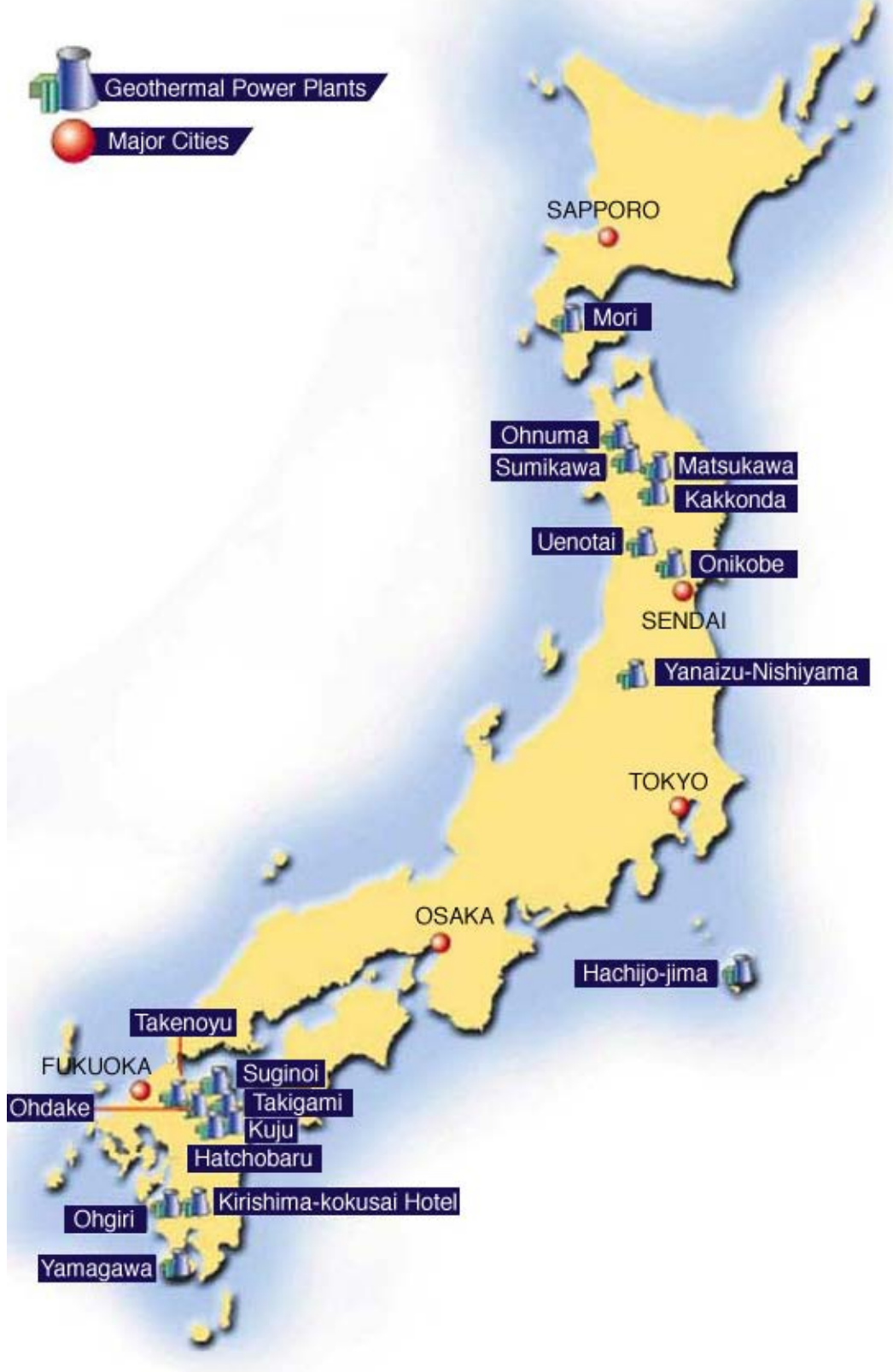

Figure 4: Geothermal Energy Project Locations in Japan (Geothermal Research Society of Japan 2010) 
Table 10: Example Geothermal Energy Projects in Japan (Kawazoe and Combs 2004)

\begin{tabular}{|c|c|c|c|c|}
\hline $\begin{array}{c}\text { Power Plant } \\
\text { Name }\end{array}$ & Location & $\begin{array}{l}\text { Project Size } \\
\text { (MW) }\end{array}$ & $\begin{array}{c}\text { Annual Energy } \\
\text { Generation (MWh) }\end{array}$ & $\begin{array}{c}\text { Start of } \\
\text { Operation }\end{array}$ \\
\hline Matsukawa & $\begin{array}{l}\text { Matsuo village, } \\
\text { Iwate }\end{array}$ & 23.5 & 171,651 & October 1966 \\
\hline Ohdake & $\begin{array}{l}\text { Kokonoe town, } \\
\text { Oita }\end{array}$ & 12.5 & 93,234 & August 1967 \\
\hline Ohnuma & $\begin{array}{l}\text { Kazuno city, } \\
\text { Akita }\end{array}$ & 9.5 & 59,378 & June 1974 \\
\hline Onikobe & $\begin{array}{l}\text { Naruko town, } \\
\text { Miyagi }\end{array}$ & 12.5 & 80,643 & March 1975 \\
\hline Hatchobaru 1 & $\begin{array}{l}\text { Kokonoe town, } \\
\text { Oita }\end{array}$ & 55.0 & 333,697 & June 1977 \\
\hline Kakkonda 1 & $\begin{array}{l}\text { Shizukuishi } \\
\text { town, Iwate }\end{array}$ & 50.0 & 230,414 & May 1978 \\
\hline Suginoi & Beppu City, Oita & 3.0 & 9,383 & March 1981 \\
\hline Mori & $\begin{array}{l}\text { Mori town, } \\
\text { Kayabe-gun, } \\
\text { Hokkaido }\end{array}$ & 50.0 & 184,794 & November 1982 \\
\hline $\begin{array}{l}\text { Kirishima } \\
\text { Kokusai Hotel }\end{array}$ & $\begin{array}{l}\text { Makizono town, } \\
\text { Kagoshima }\end{array}$ & 0.1 & 611 & February 1984 \\
\hline Hatchobaro 2 & $\begin{array}{l}\text { Kokonoe town, } \\
\text { Oita }\end{array}$ & 55.0 & 450,987 & June 1990 \\
\hline Takenoyu & & 0.05 & & October 1991 \\
\hline Uenotai & $\begin{array}{l}\text { Yuzawa city, } \\
\text { Akita }\end{array}$ & 28.8 & 205,679 & March 1994 \\
\hline Yamagawa & $\begin{array}{l}\text { Yamagawa town, } \\
\text { Kagoshima }\end{array}$ & 30.0 & 153,504 & March 1995 \\
\hline Sumikawa & $\begin{array}{l}\text { Kazuno-ciry, } \\
\text { Akita }\end{array}$ & 50.0 & 353,498 & March 1995 \\
\hline $\begin{array}{l}\text { Yanauzu- } \\
\text { Nishiyama }\end{array}$ & $\begin{array}{l}\text { Yanaizu-ciry, } \\
\text { Fukushima }\end{array}$ & 65.0 & 399,661 & May 1995 \\
\hline Ogiri & $\begin{array}{l}\text { Makizono \& } \\
\text { Kurino towns, } \\
\text { Kagoshima }\end{array}$ & 30.0 & 262,369 & March 1996 \\
\hline Kakkonda 2 & $\begin{array}{l}\text { Shizukuishi } \\
\text { town, Iwate }\end{array}$ & 30.0 & 242,310 & March 1996 \\
\hline Takigami & $\begin{array}{l}\text { Kokonoe town, } \\
\text { Oita }\end{array}$ & 25.0 & 215,165 & November 1996 \\
\hline Kuju & & 2.0 & 5,368 & April 1998 \\
\hline Hachijojima & $\begin{array}{l}\text { Hachijo Town, } \\
\text { Tokoyo }\end{array}$ & 3.3 & 14,964 & March 1999 \\
\hline
\end{tabular}

Japan has two geothermal power equipment manufacturers: MHI and Fuji Electric System Co., Ltd. Fuji Electric Systems has focused its efforts on small binary plants that are able to utilize geothermal fluids with temperatures below 130 to $140^{\circ} \mathrm{C}$ (266 to $284^{\circ} \mathrm{F}$ ). Fuji hopes to hold $50 \%$ of the market share for geothermal power generation facilities world-wide by FY 2011 (Denki Shimbun 2009). MHI has supplied the geothermal generating equipment for 14 of the units currently in operation in Japan, responsible for 272.3 MW of production (MHI 2010). 


\section{Obstacles to Development in Japan}

One of the major obstacles to development of geothermal energy in Japan is that many of the most attractive areas in terms of resource potential are located in protected areas in national parks or quasi-national parks where such development is prohibited (Koshiba 2009). Compliance with the many requirements such as the Hot Springs Act, the Environmental Impact Assessment Act, the Electricity Utilities Industry Law, and others restrict access and increase the cost of both development and electricity generation.

In addition to regulatory obstacles, development is often opposed by tourism industries concerned with possible degradation of hot springs, which are visited by travelers and locals alike. However, the long history of geothermal power generation has provided knowledge of how to develop geothermal generation projects without impacting hot springs.

\section{Data Sources}

Data sources available for geothermal assessments in Japan are similar to what is used for assessments in the US, although the particular resources used for US assessments do not contain data on Japan. The Japanese geothermal assessment will rely on the following resources.

- Geothermal Gradient and Heat Flow Data in and around Japan (Tanaka 2004) is a database available on CD-ROM that has been purchased. It contains an extensive well database (including well ID, latitude/longitude coordinates, drill depth, conductivity, heat flow, and temperature gradients for each well). The CD-ROM also contains maps that display the well data as color-coded points with each color shade representing a given range of heat flow or temperature gradient.

- Geothermal Potential Map in Japan (Geological Survey of Japan 2009). This CD-ROM contains geospatial data using the same data as the first resource (but updated in 2009) to display contours for temperature gradients and heat flow.

\section{Approach}

To prepare for the economic analysis of geothermal projects at Japanese installations, the geothermal resource availability at each location must first be determined. The listed data sources will provide the necessary resource information, similar to what is collected for a USbased assessment.

For commercial use, it is necessary to have a geothermal reservoir capable of providing hydrothermal (hot water and steam) resources with sufficiently high flow rates. Successful geothermal electrical power generation requires fluid flow rates equal to or greater than 1,000 gallons per minute (gpm) per MW. Heat flow values above $80 \mathrm{~mW} / \mathrm{m}^{2}$ are considered characteristic of a viable geothermal resource. Productive heat flows are generally greater than $150 \mathrm{~mW} / \mathrm{m}^{2}$ (Blackwell et al. 2003). In addition to sufficiently high flow rates, utility grade geothermal energy requires temperatures in excess of $100^{\circ} \mathrm{C}\left(212^{\circ} \mathrm{F}\right)$ at depths less than $3 \mathrm{~km}$ (1.9 mi).

The baseline analysis for a geothermal resource assumes a binary cycle power plant. Binary plants utilize lower temperature resources than other technologies. Given the number of geothermal power plants already in operation in Japan, it is likely that the remaining available

Renewable Energy Assessment Methodology for Japanese OCONUS Army Installations

Pacific Northwest National Laboratory, August 2010 
resources will be at lower temperatures. For preliminary analysis, a $5 \mathrm{MW}$ plant will be assumed. A more detailed analysis will match the plant size to the installation load.

\section{Ground Source Heat Pumps}

\section{Background}

\section{Ground Source Heat Pump Technology}

GSHPs generally consist of two main technical components that differ from traditional heating and cooling systems: a water source heat pump (WSHP) and a ground coupled heat exchanger (GCHX). The WSHP operates on the same principal as a typical air conditioner, but has been modified to allow it to work in two directions. Essentially, it can either air-condition the interior of a building or the exterior of a building (which in turn heats the inside); depending on which operating mode it is set to. Another characteristic of WSHPs that differentiate them from standard air conditioners is the fact that the exterior coils are designed to interact with water rather than air. This can be seen in some large commercial building chillers, but is rare in smaller systems, which are typically directly air-cooled.

The GCHX portion of GSHP systems allows the WSHP to exchange energy with the earth and take advantage of the consistent annual temperatures found below the earth's surface. There are a number of different configurations of GCHXs, including open-loop, horizontal closed-loop, and vertical closed-loop.

$\checkmark$ Open-loop systems use wells or open bodies of water as direct heat transfer mediums to provide cooler temperatures in the summer and warmer temperatures in the winter. Heat transfer is only needed once, at the building, because groundwater is used directly.

$\checkmark$ Horizontal closed-loop systems use heat transfer fluid inside a sealed pipe to exchange heat with the earth. The heat exchange pipe is buried in a trench dug about 6 feet below the surface. Heat transfer occurs twice in this system: between the heat transfer fluid and the soil, and in the building between the heat transfer fluid and the refrigerant.

$\checkmark$ Vertical closed-loop GSHPs operate on the same principal as horizontal loops, with a sealed ground loop and heat transfer occurring twice. However, in this case, the heat transfer piping is installed vertically in boreholes up to 300 feet deep.

GSHPs are applicable in almost any building with both heating and cooling. They can be used in buildings as small as $100 \mathrm{ft}^{2}$ or as large as $1,000,000 \mathrm{ft}^{2}$. Multiple GSHPs can be used in a single building to meet the load, or the same ground loop can be shared between buildings.

\section{Obstacles to Development in Japan}

Japan currently is estimated to have only around 400 GSHPs installed in the entire country. The lack of GSHP penetration is generally attributed to the high cost of heating with electricity, compared to available fossil fuels (Morita 2009). At fossil fuel prices roughly one-third those of electricity, the economics of GSHP installations become less clear and highly sensitive to environmental conditions, which also can be unfavorable in Japan.

Renewable Energy Assessment Methodology for Japanese OCONUS Army Installations Pacific Northwest National Laboratory, August 2010 
Japan is perceived to have poor soil conditions for drilling bore holes (Morita 2009) - the rocky and variable terrain can drive up initial costs for GSHP installations. Local regulations governing the use of groundwater sometimes do not allow open-loop GCHXs because of concern about groundwater depletion or contamination. Land availability may be another issue. Individual trenches in horizontal systems are spaced between 6 and 12 feet apart. The boreholes in vertical systems need to be spaced 15 to 20 feet apart. Piping requirements are 100 to 400 feet per cooling ton for horizontal systems and 200 to 600 feet per cooling ton for vertical systems, so sufficient land area is a necessity.

The combination of land availability and local regulations make $77 \%$ of Japan off limits to any sort of ground source heat exchange. Of the remaining 23\%, 17\% is limited to closed-loop heat exchangers; only 19\% of Japan's land area is useable for both open- and closed-loop systems (Hamadaa et al. 2002).

\section{Ground Source Heat Pump Projects in Japan}

There have been attempts in the past to increase the level of GSHP use in Japan, such as an effort launched in 2001 for 140,000 installations by 2010, and a 2003 government program to install GSHP systems in 60 public facilities across the country. It is unclear how successful the latter program was, but the former was certainly not (Kasumi and Shinji 2003). Despite this, there are some GSHP installations in Japan with uses ranging from snow melting systems to air conditioning and water heating. Some are shown in Table 11.

Table 11: Example GSHP Projects in Japan (Geo-Heat Promotion Association of Japan 2010)

\begin{tabular}{||l|l|l|l|l||}
\hline \multicolumn{1}{|c|}{ Project Name } & \multicolumn{1}{c|}{ Location } & Year Built & \multicolumn{1}{c|}{ System Function } & \multicolumn{1}{c|}{ Size } \\
\hline $\begin{array}{l}\text { IRIS Senior Public } \\
\text { Health Center }\end{array}$ & Hino, Tokyo & March 2004 & $\begin{array}{l}\text { Space conditioning, } \\
\text { service water heating, } \\
\text { snow melting }\end{array}$ & $\begin{array}{l}163 \mathrm{~kW} \text { (heating), } \\
145 \mathrm{~kW} \text { (cooling); } \\
20 \text { heat exchange } \\
\text { wells } 50 \mathrm{~m} \text { deep }\end{array}$ \\
\hline $\begin{array}{l}\text { Yoshida Town (Akitaka } \\
\text { Town) Indoor Pool }\end{array}$ & $\begin{array}{l}\text { Akitataka City, } \\
\text { Hiroshima } \\
\text { Prefecture }\end{array}$ & $\begin{array}{l}\text { February } \\
2005\end{array}$ & $\begin{array}{l}\text { Space conditioning, } \\
\text { service water heating, } \\
\text { snow melting }\end{array}$ & $\begin{array}{l}\text { 480 } \mathrm{kW} \text { (heating); } \\
\text { wells } 100 \mathrm{~m} \text { deep }\end{array}$ \\
\hline $\begin{array}{l}\text { Misawa Environmental } \\
\text { Engineering Corporation } \\
\text { Offices and Geothermal } \\
\text { Equipment Installation } \\
\text { Business }\end{array}$ & $\begin{array}{l}\text { Misawa City, } \\
\text { Hiroshima } \\
\text { Prefecture }\end{array}$ & $\begin{array}{l}\text { December } \\
1991\end{array}$ & $\begin{array}{l}\text { Space conditioning, } \\
\text { service water heating }\end{array}$ & $\begin{array}{l}13 \mathrm{~kW} \text { (Heating); } \\
2 \text { heat exchange } \\
\text { wells } 100 \mathrm{~m} \text { deep }\end{array}$ \\
\hline
\end{tabular}

Due to the relative scarcity of GSHP installations in Japan, there are few widely-advertised manufacturers. The most well-known is Mitsubishi. Finding experienced designers and installers may also be difficult, yet imperative for proper system operation. Misawa Environmental Engineering Corporation installed two of the heat pumps listed in Table 10, including the one at its own facility. Other installers can be found at the link below.

\section{Data Sources}

Due to the high variability of ground conditions in Japan and the important role that locationspecific factors play in assessing the economic viability of a GSHP project, the best place to obtain detailed information about a site is from the site itself. If any sort of detailed GSHP 
assessment has been completed in the past for a particular site, the results should be used to refine the current assessment, especially with regards to

- Soil conditions

- Bedrock depth

- Water table depth

- Groundwater temperature

A good source for case studies can be found at http://www.geohpaj.org/introduction/examenu.htm.

For more general information of soil and rock conditions throughout Japan, the following are good resources for general information on Japan’s geological and hydrological conditions.

- $\quad$ http://riodb02.ibase.aist.go.jp/db084/index_e.html

- $\quad$ http://www.aist.go.jp/GSJ/

For detailed typical weather conditions to help simulate heating and cooling requirements, this link provides data for a number of sites across Japan:

http://apps1.eere.energy.gov/buildings/energyplus/cfm/weather_data3.cfm/region=2_asia_wmo_ region_2/country=JPN/cname=Japan.

Current and historical weather data can be found at http://lwf.ncdc.noaa.gov/oa/land.html.

A listing of professionals that work in this and related fields is available at http://www.geohpaj.org/link/memlist.htm.

\section{Approach}

In order to asses a site's suitability for the installation of GSHPs, PNNL utilizes FEDS (see Economic Evaluation of OCONUS Renewable Projects section above) to develop a detailed analysis of complex factors that impact economics of a GSHP project. The FEDS software was developed for use in North America, but it can be tailored for analysis of any location. The key site characteristics used in the analysis are

- Fossil fuel costs and availability, including

o Natural gas

o Distillate oil

o Residual oil

o Coal

o Purchased steam

o Purchased hot water

o Purchased chilled water

o Other

Renewable Energy Assessment Methodology for Japanese OCONUS Army Installations Pacific Northwest National Laboratory, August 2010 
- Electricity costs, taking into account detailed rate structures, including

o Seasonal variation

o Time of day

o Demand charges

o Demand ratchets

- Soil and groundwater characteristics

o Soil type near surface

o Soil thermal diffusivity

o Overburden depth

o Bedrock thermal conductivity

o Aquifer depth

o Groundwater temperature

- Weather

Default values are available for weather and soil and groundwater characteristics at North American locations, but for Japanese sites this data must be obtained from the site being examined and entered in place of default values.

In order to capture the building characteristics represented on a particular site, there are two different approaches that can be employed. The method selected depends on whether or not a complete installation-wide FEDS assessment has already been completed for the site. Key information to be collected from the site for this type of analysis includes

- List of demolished buildings

- List of new buildings (if FEDS assessment is more than 6 years old)

If, within the last 6 years, a FEDS assessment has been completed for the site in question, as is the case of Camp Zama, the FEDS model built for that assessment can be used directly for the GSHP analysis. Any buildings built since the assessment was completed will not need to be added because of the negative economic implications of replacing new heating and cooling equipment. Buildings that have been demolished can be removed from the model, but leaving them in will have no effect on the projects proposed for the remaining structures.

If the previous FEDS analysis is more than 6 years old, to avoid missing any potentially economic projects it will be necessary to obtain a list of all newer buildings and add them to the original FEDS model.

In the case when a site has never had a comprehensive FEDS analysis completed, as is the case for all Japanese sites except Camp Zama, a different approach must be taken. This second approach uses generic sets of buildings that can then be used by the installation to identify likely projects from their building stock. Renewable Energy Assessment Methodology for Japanese OCONUS Army Installations
Pacific Northwest National Laboratory, August 2010 
The generic sets contain buildings with the following characteristics:

- Use type
o Administration
o Barracks

- Age

o Old: 1945

o Mid Aged: 1975

o New: 2000

- Size

o Small: $500 \mathrm{ft}^{2}$

o Medium: $10,000 \mathrm{ft}^{2}$

o Large: $100,000 \mathrm{ft}^{2}$

- Heating technology

o Single building boiler

- Air handling units

- Fan coil units

o Furnace

o Central steam

- Air handling units

- Fan coil units

o Central hot water

- Air handling units

- Fan coil units

o Air source heat pump

o Electric resistance

- Cooling technology

o Single building chiller

- Air handling units

- Fan coil units

o Central chilled water

- Air handling units

- Fan coil units 
o Air source heat pump

o Packaged or split system DX unit

o Through window/wall units

Each possible combination of the above characteristics and each fuel type applicable to that combination are represented in the generic models. In order to tailor the generic model to a site, it is necessary to determine which of these combinations does not occur on site and eliminate them from the model. Generally, this includes certain fuels and central plants. For Japanese sites, standard building characteristics found at Camp Zama will be included in the generic Hiroshima and Okinawa models as well.

When the generic model has been modified to reflect existing conditions as much as possible, the analysis can be completed in the same manner as with a full site model. 
Renewable Energy Assessment Methodology for Japanese OCONUS Army Installations Pacific Northwest National Laboratory, August 2010 


\section{Applicability}

This methodology was developed for OCONUS Army installations located in Japan, and it can be used for any US military installation in Japan. This same methodology can be adapted for use at other OCONUS installations as well, with an adjustment of data sources. Some of the data sources listed here are Japan-specific, and some are US-based that cover Japan but may not cover all countries. Data sources specific to the country of interest would need to be researched.

Additionally, regulatory issues will change with each new location. These include available sources of funding, potential for local or other contractors to build energy systems for/at US operations, ability to connect to electric grids, and ability to sell energy to the installation, local utility, or other customers. As mentioned, these issues do not need to be resolved during an initial feasibility assessment, but should be considered when considering the practical potential of promising projects. 
Renewable Energy Assessment Methodology for Japanese OCONUS Army Installations Pacific Northwest National Laboratory, August 2010

34 


\section{Potential Issues}

Using this methodology for Japanese renewable energy analyses should result in consistent, comparable, and usable recommendations for US military installations. However, some issues may arise with relating to the Japanese government and local communities, cross-continental communication, and limited access to Japanese resources.

The resentment most Japanese feel toward the presence of the US military may be a hindrance to project development and the willingness of private developers to contract with the US government. This situation may make the ability to gather data about Japanese resources and build renewable energy projects on US military land in Japan quite complicated and difficult to fund. Development of a large renewable energy project for the US military may require extensive conversations and negotiations with local personnel. However, Japan's need for more renewable energy to meet goals and increase energy self-sufficiency may prompt the support of new renewable generation on US military installations.

The expense of traveling for Japanese site visits limits PNNL to just one. While that is standard practice for analyses at US installations, much more information is typically readily available for US installations. A US installation in Japan or another foreign country does not necessarily have established connections with the government or local community, and so additional investigations are required to discover what contracts, incentives, and other assistance or partnerships will be available for renewable energy development. If this information is not able to be collected during the site visit, it may be extremely difficult to track down after returning to the US. A carefully planned trip with ample time to talk to all necessary personnel will help avoid this potential problem.

In addition, there is a 16-hour time difference between the US Pacific time zone and Japan. With very limited face-to-face time, PNNL must rely on other communication methods. Phone calls are restricted to late afternoons for PNNL and early mornings for personnel in Japan. Therefore, most communication must be through email. While this is not a large imposition, it does result in a time delay between responses.

PNNL personnel have limited experience with the Japanese language, and translating online or other resources only available in Japanese could become time-consuming and inaccurate. PNNL must rely, to an extent, on personnel located at the Japanese installations to ensure a complete and correct translation of many data resources. Personnel at Camp Zama have been extremely helpful with this matter so far. 
Renewable Energy Assessment Methodology for Japanese OCONUS Army Installations Pacific Northwest National Laboratory, August 2010

36 


\section{Summary and Conclusion}

PNNL's established methodology for analyzing the potential for renewable power generation projects at CONUS installations is largely applicable to OCONUS installations as well. Many data sources used include locations worldwide, and US-only resources have been found to have equivalent resources specific to Japan. Data availability does not seem to be an obstacle, and so renewable resource availability can be estimated with limited adjustment to the CONUS methodology.

Similarly, the economic portion of the assessment needs minimal adjustment for use at OCONUS installations. The potential for development of a resource can be determined using the same financing methods available in the US, many if not all of which are also available to US agencies located abroad. The primary factors needing adjustment for OCONUS assessments are project costs, available incentives, and applicable taxes. This information is easily attainable through a site visit and publicly available information.

Project implementation, the next step following this feasibility assessment, will be more challenging than in the US, especially for large projects requiring outside financing. They will require extensive discussions with installation personnel and key local contacts to fully understand the regulations and opportunities surrounding a project that will affect the entire community. This feasibility study is important to identify which projects are worthwhile to pursue in this manner and what level of involvement will be required. 
Renewable Energy Assessment Methodology for Japanese OCONUS Army Installations Pacific Northwest National Laboratory, August 2010

38 


\section{References}

Agency for Natural Resources and Energy. Energy in Japan 2008. Ministry of Economy, Trade and Industry. Tokyo, Japan. Accessed February 2010 at

http://www.enecho.meti.go.jp/english/toprunnner/index.html.

Asahi Kasei Corporation. June 18, 2008. Utilization of wood biomass fuel for power generation. Accessed February 2010 at http://www.asahikasei.co.jp/asahi/en/news/2008/e080618.html.

Asia Biomass Office. 2010. Six Coal-burning Power Stations Adopted Biomass Co-firing Using Forest Residue. Accessed February 2010 at http://www.asiabiomass.jp/english/topics/1002_01.html.

Associated Press. March 24, 2010. LEAD: Japan eyeing more nuclear power plants to fight global warming. Accessed March 25, 2010 at http://www.breitbart.com/article.php?id=D9EL01QO0\&show_article=1.

Blackwell, D, et al. 2003. Geothermal Resource Analysis and Structure of Basin and Range Systems, Especially Dixie Valley Geothermal Filed, Nevada. Department of Geological Sciences Southern Methodist University. Accessed February 2010 at http://www.osti.gov/energycitations/servlets/purl/813485-smnwbs/native/813485.PDF.

Cleveland, Cutler J., ed. December 22, 2006. "Energy profile of Japan." Encyclopedia of Earth. Washington, D.C. Accessed March 2010 at http://www.eoearth.org/article/Energy_profile_of_Japan (last updated January 31, 2007).

Denki Shimbun. August 7, 2009. Fuji Electric Systems to pursue over 50\% global market share in geothermal facilities. Accessed March 30, 2010 at

http://www.shimbun.denki.or.jp/english/article/2009080702.shtml.

EIA - Energy Information Association. 2008. International Energy Statistics. Accessed March 2010 at http://tonto.eia.doe.gov/cfapps/ipdbproject/IEDIndex3.cfm.

Energy Conservation and Renewable Energy Department. 2009. New Buyback Program for Photovoltaic Generation. Agency for Natural Resources and Energy, Ministry of Economy, Trade, and Industry. Presentation provided by Camp Zama personnel. November 2009.

Englander, D. April 23, 2008. “Japan’s Wind-Power Problem.” GreenTechMedia. Accessed February 2010 at http://www.greentechmedia.com/articles/read/japans-wind-power-problem$\underline{828 / .}$

Fackler, M. June 1, 2010. “Japan’s Premier Will Quit as Approval Plummets.” The New York Times. Accessed June 4, 2010 at http://www.nytimes.com/2010/06/02/world/asia/02japan.html?hp.

Foster, R. 2005. Japan Photovoltaics Market Overview. Accessed February 2010 at http://solar.nmsu.edu/publications/Japan\%20Report.pdf. 
GE Energy. March 11, 2008. GE Energy's Jenbacher Gas Engines Successfully Power Japan's Largest Wood Gas Power Plant. Accessed February 2010 at http://www.gepower.com/about/press/en/2008_press/031108.htm.

Geo-Heat Promotion Association of Japan. 2010. Example Installations by Prefecture. Accessed March 2010 at http://www.geohpaj.org/introduction/prefecture.htm.

Geological Survey of Japan. 2009. Geothermal Potential Map in Japan.

Geothermal Research Society of Japan. 2010. Geothermal Energy in Japan. Accessed February 2010 at http://www.soc.nii.ac.jp/grsj/index-e.html.

GWEC - Global Wind Energy Council. 2009. Japan. Accessed December 2009 at http://www.gwec.net/index.php?id=123.

Hamada, Y, K Marutani, M Nakamura, S Nagasaka, K Ochifujia, S Fuchigami, and S Yokoyama. July-August 2002. "Study on Underground Thermal Characteristics by Using Digital National Land Information, and its Application for Energy Utilization.” Applied Energy, 659-675. Accessed February 2010 at http://www.sciencedirect.com/science?_ob=MImg\&_imagekey=B6V1T-46SFHJM-2$11 \& \_$cdi $=5683 \&$ \& user $=8252820 \& \_p i i=S 0306261902000557 \& \_$orig $=$search \&_coverDate $=08 \% 2$ F31\%2F2002\&_sk=999279996\&view $=$ c\&wchp $=$ dGLbVtbzSkWb\&md5=93eb448a5b404f9891b396531b02f032\&ie=/sdarticle.pdf.

Honda, J. 2007. History of Photovoltaic Industry Development in Japan. Proceedings of ISES World Congress 2007 (Vol. I - Vol. V). Accessed February 2010 at http://www.springerlink.com/content/n26v522u50212g05/.

Japan for Sustainability. December 12, 2008. 100 Million kWh Wind Farm Begins Operation in Kyushu. Accessed December 2009 at http://www.japanfs.org/en/pages/028558.html.

JETRO - Japan External Trade Organization. April 2007. “Taxes in Japan: Fact Sheet.” Accessed June 3, 2010 at http://www.jetro.org/content/253.

JETRO - Japan External Trade Organization. 2010. "Investing in Japan: Section 3. Taxes in Japan.” Accessed June 3, 2010 at http://www.jetro.go.jp/en/invest/setting_up/laws/section3/page3.html.

JNEC - Japan Natural Energy Company. 2001. Accessed August 2009 at http://www.naturale.co.jp/english/index.html.

JNEC - Japan Natural Energy Company. 2003. Green Power Marketing in Japan. Accessed August 2009 at www.isep.or.jp/e/kako/img/takeshi_syouda_p2.pdf.

Kasumi, Y and T Shinji. July 2003. "Present Status of Underground Thermal Utilization in Japan.” Geothermics, 609-618. Accessed February 2010 at http://www.sciencedirect.com/science?_ob=MImg\&_imagekey=B6VCN-49P4794-DN\&_cdi $=5959 \& \_u s e r=8252820 \& \_p i i=S 0375650503000889 \& \_$orig $=$search\&_coverDate $=12 \% 2$ 
F31\%2F2003\&_sk=999679995\&view=c\&wchp=dGLbVlWzSkWb\&md5=08c1ada0085bdf1ea36dc3bef55e49c2\&ie=/sdarticle.pdf.

Kawazoe, S and J Combs. March/April 2004. "Geothermal Japan: History and Status of Geothermal Power Development and Production.” Geothermal Resources Council GRC Bulletin. Accessed February 2010 at http://www.geothermal.org/articles.html.

Koch, E. June 2008. “Blending Aesthetics \& Energy.” Biomass Magazine. Accessed February 2010 at http://www.biomassmagazine.com/article.jsp?article_id=1677\&q=\&page=2.

Kora, AR, DR Brown, and DR Dixon. 2010. Facility Energy Decision System (FEDS) Assessment Report for U.S. Army Garrisson, Japan - Honshu Installations. Pacific Northwest National Laboratory, Richland, Washington. PNNL-19232. March 2010.

Koshiba, K. December 2009. “Current Status and Future Prospects of Geothermal Energy Use in Japan.” Japan for Sustainability, 88. Accessed February 2010 at http://www.japanfs.org/en/mailmagazine/newsletter/pages/029640.html.

Lawrence Berkeley National Laboratory. 2009. Tracing the Sun: The Installed Cost of Photovoltaics in the U.S. from 1998-2007. Accessed February 2010 at http://eetd.lbl.gov/ea/EMS/reports/lbnl-1516e.pdf.

Lenardic, Denis. 2010. Large-scale photovoltaic power plants ranking 1 - 50. pvresources.com. Accessed February 2010 at http://www.pvresources.com/en/top50pv.php (last updated February 14, 2010).

MAFF - Japan Ministry of Agriculture, Forestry, and Fisheries Forestry Agency. 2009. Annual Report on Trends in Forest and Forestry Fiscal Year 2008 (Summary). Accessed February 2010 at http://www.rinya.maff.go.jp/j/kikaku/hakusyo/20hakusho/pdf/20_e.pdf.

METI - Japan Ministry of Economy, Trade and Industry. 2010. Present Status and Promotion Measures for the Introduction of Renewable Energy in Japan. Accessed February 2010 at http://www.meti.go.jp/english/policy/energy_environment/renewable/index.html (last updated January 2010).

MHI - Mitsubishi Heavy Industries, Ltd. 2010. Mitsubishi’s experience in supplying geothermal generating equipment. Accessed March 2010 at http://www.mhi.co.jp/en/products/detail/geothermal_power_plant_experience.html.

Mitsubishi. 2003. The first $2000 \mathrm{~kW}$ Wind Turbine Generator in Japan starts operation at Okinawa. Copy of Press Release received from Jeff Molony.

MOE - Japan Ministry of the Environment. 2009. Annual Report on the Environment and the Sound Material-Cycle Society in Japan 2009 (General Summary of "Sound Material-Society" Section). Accessed February 2010 at http://www.env.go.jp/en/recycle/smcs/arep/2009gs_full.pdf.

Renewable Energy Assessment Methodology for Japanese OCONUS Army Installations Pacific Northwest National Laboratory, August 2010 
Morita, K. 2009. Field Test of a Ground Source Air-Conditioning and Hot Water Supply System in a Single Family House. National Institute of Advanced Industrial Science and Technology, Tsukuba, Ibaraki. Accessed February 2010 at http://www.aist.go.jp/aist_e/research_results/publications/pamphlet/today/new_energy_technolo gy_for_society.pdf.

Nakata, H. July 9, 2008. Nature stifling wind power in Japan. The Japan Times Online. Accessed December 2009 at http://search.japantimes.co.jp/cgi-bin/nb20080709a1.html.

PNL and NREL - Pacific Northwest Laboratory and National Renewable Energy Laboratory. 1986. Wind Energy Resource Atlas of the United States. Solar Technical Information Program \& Solar Energy Research Institute, Golden, Colorado. Accessed at http://rredc.nrel.gov/wind/pubs/atlas/atlas_index.html.

Siegel, J. November 2009. Larger Turbines Seeking Place in U.S. Market. North American Windpower, Waterbury, Connecticut.

Siegel, J, S McNulty, and J Weingard. 2010. Renewable Energy for Urban Application in the APEC Region. Accessed February 2010 at http://publications.apec.org/publicationdetail.php?pub_id=980.

Solarbuzz. 2009. “Japanese PV Market.” Fast Facts Japan. The NPD Group. Accessed February 2010 at http://www.solarbuzz.com/FastFactsJapan.htm.

Tanaka, A, M Yamano, Y Yano, and M Sasada. 2004. Geothermal Gradient and Heat Flow Data in and around Japan. Earth Planets Space, 56, 1191-1194.

TaxRates.cc. 2009. “Japan Tax Rates.” Accessed June 2010 at http://www.taxrates.cc/html/japan-tax-rates.html (last updated 2010).

Tetsunari, Iida and Andrew DeWit. September 21, 2009. "Is Hatoyama Reckless or Realistic? Making the Case for a 25\% Cut in Japanese Greenhouse Gases." The Asia-Pacific Journal, Vol 38-4-09. Accessed March 2010 at http://www.japanfocus.org/-Andrew-DeWit/3226. 


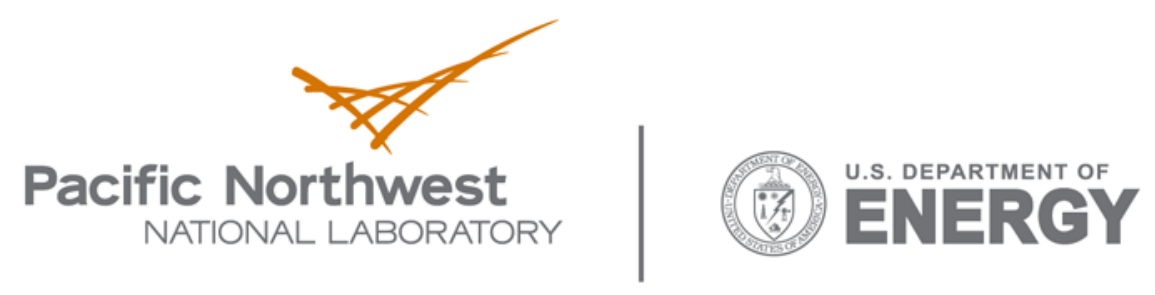

902 Battelle Boulevard

P.O. Box 999

Richland, WA 99352

1-888-375-PNNL (7665)

www.pnl.gov 